\title{
Short- to medium-term effects of crown and surface fires on soil respiration in a Canadian boreal forest
}

Caius Ribeiro-Kumara*1, Cristina Santín ${ }^{2,3}$, Stefan H. Doerr ${ }^{4}$, Jukka Pumpanen ${ }^{5}$, Greg Baxter ${ }^{6}$, Kajar Köster ${ }^{1,7}$

$5{ }^{1}$ Department of Forest Sciences, University of Helsinki, Institute for Atmospheric and Earth System Research/Forest Sciences, Helsinki, Finland

${ }^{2}$ Research Institute of Biodiversity (IMIB; Spanish National Research Council-University of Oviedo-Principality of Asturias), Mieres, Spain

${ }^{3}$ Department of Biosciences, Swansea University, Swansea, Wales, United Kingdom

$10 \quad{ }^{4}$ Department of Geography, Swansea University, Swansea, Wales, United Kingdom

${ }^{5}$ Department of Environmental and Biological Sciences, University of Eastern Finland, Kuopio, Finland

${ }^{6}$ Wildfire Operations Research, FPInnovations, Edmonton, Alberta, Canada

${ }^{7}$ Department of Environmental and Biological Sciences, University of Eastern Finland, Joensuu, 15 Finland

*Corresponding author (caius.ribeiro@helsinki.fi) 


\begin{abstract}
Fires are an important perturbation for the carbon (C) dynamics of boreal forests, especially when they are stand-replacing. In North American boreal forests, crown fires are predominant and,

20 therefore, the most studied. However, surface fires can also lead to major tree mortality with substantial implications for the $\mathrm{C}$ balance. Here, we assess the short- (hours - days) to mediumterm ( $1-3$ years) effects of the different fire types (surface vs. crown) on the postfire soil C effluxes in jack pine and black spruce forest stands in the Northwest Territories, Canada. We found that while trees were instantly killed by the four crown fires studied, trees also died within one year

25 after two of three surface fires studied. Associated with this tree mortality, soil autotrophic respiration decreased after both fire types, although at different timings. The soil heterotrophic respiration was either lower or unchanged when measured $1-3$ years after either fire type but was increased when measured immediately after a surface fire, possibly due to the interaction between ash generation and wetting performed to suppress the fire. Our results suggest that both fire types can thus substantially alter $\mathrm{C}$ fluxes in the short- to medium-term, both through changes in vegetation and the soil environment.
\end{abstract}

Keywords: soil autotrophic respiration, soil heterotrophic respiration, soil $\mathrm{CO}_{2}$ efflux, tree mortality, fire disturbance 


\section{Introduction}

40 The boreal biome occupies nearly one-third of the global forested land, and about $66 \%$ and $30 \%$ of the world's forest carbon (C) pool is stored in their soil and vegetation, respectively (Burton et al., 2003; Kasischke, 2000). Boreal forests are generally $\mathrm{C}$ sinks $\left(0.5 \pm 0.1 \mathrm{Pg} \mathrm{C}_{\mathrm{gear}}{ }^{-1}\right)$, but they can become transient $\mathrm{C}$ sources due to disturbances such as fires (Pan et al., 2011; Zhao et al., 2020). Increased fire activity associated with the warming climate may lead this biome to act as a long-term regional C source, as seen in Alaska and Canada during 1986 - 2016 (Zhao et al., 2020). Although fires rapidly release large amounts of $\mathrm{C}$ to the atmosphere through the combustion of foliage, twigs, branches, coarse woody debris, and soil organic matter, the majority of C loss occurs during the postfire decomposition of fire-killed vegetation, where $\mathrm{C}$ is slowly released over decades (Kurz et al., 2013). Postfire C effluxes from soils (soil respiration) can be divided into two main components: i) soil heterotrophic respiration, the decomposition of soil organic matter, and ii) soil autotrophic respiration, derived from the metabolic activity for growth and maintenance of autotrophic organisms living in the soil (i.e. algae and some bacteria) and of plant roots and associated mycorrhiza (Högberg et al., 2001). Postfire variations in these two main sources of $\mathrm{CO}_{2}$ efflux to the atmosphere are determined by the combined fire impacts above- and belowground

55 (i.e. by burn severity) (Kurz et al., 2013).

Wildfires are therefore a key perturbation affecting the $\mathrm{C}$ budget of boreal forests, with the fire type (crown, surface, or ground fire) being a fundamental factor affecting postfire C fluxes (Gonzalez-Perez et al., 2004). The fire regime in the North American boreal forests is characterized by high-intensity crown fires, typically at an interval of $100-180$ years (de Groot et al., 2013;

60 Johnstone et al., 2010). Such fires immediately kill most of the vegetation (i.e. stand-replacing fires) and may consume part of the forest floor, impairing tree roots and microbes (Köster et al., 
2021). In the Eurasian boreal forests, surface fires dominate, which typically occur at a shorter interval ( $25-100$ years). Although they usually do not kill the trees directly, significant stand mortality may occur through soil destabilization and heat-induced necrosis of tree stem and root

65 cells (Conard \& Ivanova, 1997; Michaletz \& Johnson, 2007). In addition, surface fires may cause severe disturbance to the soil microbiota, which will also affect $\mathrm{C}$ fluxes after the fire (Köster et al., 2021). Although only about $10 \%$ of wildfires in North American boreal forests are surface fires, tree mortality after surface fires is overwhelmingly higher than in Eurasia due to the dominance of thin-barked tree species (Ryan, 2002; Wirth, 2005). Comparatively few studies have focused on

70 the belowground effects of surface fires in North American boreal forests, probably because crown fires are the dominant fire type here (de Groot et al., 2013).

This study aimed, therefore, to improve our understanding of the effects of fire type (crown vs surface fires) on soil C fluxes in the short- to medium-term ( 0 - 3 years $)$ in a North American boreal forest. We assessed and compared soil $\mathrm{C}$ fluxes after a range of experimental fires in jack pine 75 (Pinus banksiana Lamb.) and black spruce (Picea mariana (Mill.) BSP) forest stands in the Northwest Territories (Canada) during summer. We hypothesized that (1) soil autotrophic respiration will decrease in the short- to medium-term after both crown and surface fires relative to undisturbed forests, with a greater magnitude of change observed after crown fires; and (2) soil heterotrophic respiration will not increase in the short- to medium-term after neither crown fires nor surface fires. The latter hypothesis was posed because, although fires transfer $\mathrm{C}$ from living pools (both above- and belowground) into decomposing dead pools located mainly at and belowground (Campbell et al., 2016), fires may also reduce soil organic matter quantity and quality and affect soil properties governing microbial activity (Holden et al., 2015; Köster et al., 2021). Moreover, the decomposition of additional substrates, with either high necromass (e.g. woody 
85 debris, coarse roots) or high decomposition rates (e.g. foliage, fine roots), requires incorporation into the soil and colonization by decomposers, which may take longer than the timeframe of our study (Campbell et al., 2016).

\section{Materials and methods}

\subsection{Study site and experimental fires}

90 This study was conducted at the Canadian Boreal Community FireSmart Project wildfire experimental site (formerly known as the International Crown Fire Modelling Experiment, (ICFME)), $50 \mathrm{~km}$ northeast of Fort Providence, Northwest Territories (NT), Canada $\left(61.58^{\circ}\right.$, $117.16^{\circ} ; 160 \mathrm{~m}$ a.s.l.; Figure 1). The regional climate is dry and sub-humid, with short cool summers and long cold winters. Daily mean temperatures (1981 to 2010) range from 8.5 to 20.9 ${ }^{\circ} \mathrm{C}$ in August and -17.5 to $-25.9{ }^{\circ} \mathrm{C}$ in midwinter (Canadian Climate Normals, 2021). During the time of this study, the mean daily temperature ranged from 16.7 to $24.1{ }^{\circ} \mathrm{C}$. Annual precipitation (1981 to 2010) is $387.6 \mathrm{~mm}$, with about $239 \mathrm{~mm}$ as rainfall (Canadian Climate Normals, 2021). The fire season typically starts with snowmelt in early May, peaks in July and may continue until early September (Stocks et al., 2004). Soils are stony gravelly loam to stony gravelly sandy clay loam (Alexander et al., 2004). Permafrost is discontinuous in this region and absent at the study site.

The study site is composed mostly of mixed jack pine and black spruce stands regenerated naturally following a stand-replacing wildfire in 1931. As part of the ICFME, experimental burning sites were established across a 90-ha area in 1995 to test and calibrate the Albini crown fire behavior 105 model for conifer forests (Alexander et al., 2004). The site was divided in small forest stands (around 0.5-2.25ha each) divided by fire breaks (Fig. 1) The experimental fires carried out between 
1997 and 2000 are described in Stocks et al. (2004), while the characterization of the pre-fire overstory and understory tree canopies, ground vegetation, dead-down woody fuels, and the soil organic layer is described in Alexander et al. (2004). Since 2001, this study site has been managed by FPInnovations Wildfire Operations Research jointly with the NT Government. Experimental fires have been carried out almost every summer as part of the Canadian Boreal Community FireSmart Project for firefighter training and applied research purposes (e.g. to test the effect of various fuel treatments (thinning, mulching, underburning, etc.) on fire behavior). In addition, a reduced group of international scientists are also allowed to participate in the burns for other 115 research aims (e.g. Santín et al., 2013; Santín et al., 2015; or this study).

In the present study, field sampling took place during August 2018, using burns conducted between 2015 and 2018. The three surface fires included in this study occurred in stands dominated by jack pine, whereas the four crown fires included two jack pine- and two black spruce-dominated stands. Postfire smoldering of the soil did not occur and smoldering pockets of down wood or tree trunks were suppressed with water. A summary of the fires, their characteristics and associated Canadian Forest Fire Weather Index (FWI) System values are given in Table 1. Detailed descriptions of the individual experimental sites and how the burns were conducted are given below (in the same order than in Table 1).

[Table 1 approx. here]

Surface fire on 2/08/2018 over $10 \times 10 \mathrm{~m}$ area at stand dominated by jack pine with sparse understory with some shrubs, and a forest floor with needles, moss and lichen (Figure 2a). Ignition was performed in a back-and-forth pattern with drip torches. Flames climbing up trees were 
extinguished with waterbags, resulting in a low-intensity surface fire, with mean flame height $\sim 0.25$ $\mathrm{m}$. The fire consumed some fine fuels while leaving medium-sized fuels and $\sim 80 \%$ of the forest floor surface blackened (Figure 2b).

2017 surface fire (SF 2017)

Surface fire on 3/08/2017 over $50 \times 10 \mathrm{~m}$ area at a stand dominated by jack pine and understory consisting of shrubs and grasses (Figure 2c). The fire was ignited with a drip torch and resulted in 135 a high-intensity surface fire that could have led to a crown fire if not suppressed. Most surface fuels were consumed including large-sized fuels and the forest floor surface was covered with white ash. (Baxter \& Sharpe, 2017).

2015 surface fire (SF 2015) and crown fire (CF $2015 \mathrm{~A})$

Two fires on 23/06/2015 over $150 \times 50 \mathrm{~m}$ area at stand previously divided into treated and untreated (natural forest) sections. The treated section (north half) had undergone thinning treatments in which standing and lying deadwood were removed in 2000 and 2005, so that in 2012 stand density in the treated and untreated sections were 2433 and 6635 stems ha $^{-1}$, respectively. The treated section was mostly mature jack pine, while the untreated section had mature jack pine but, also, an evident black spruce understory and a greater abundance of shrubs. The sections were ignited simultaneously by throwing matches from 3-point ignition sites in each section. A surface fire developed in the treated section (Figure $2 \mathrm{~d}$ and $2 \mathrm{~g}$ ), while a high-intensity crown fire developed in the untreated section (Figure 2e and 2h) (Baxter, 2015).

2015 crown fire (CF 2015 B)

Crown fire on 25/06/2015 at stand with natural jack pine overstory (mostly dead) and black spruce understory (mostly living). The forest floor was a thin layer of needles, moss, and some lichen. The 
fire was ignited with a Terra Torch and resulted in a high-intensity crown fire, completely charring the crowns, and homogenizing the forest floor surface (Figure 2f) (Kapcak, 2015).

2017 crown fire (CF 2017)

Crown fire on 2/08/2017 over 40-m-wide strip at stand with jack pine overstory and a black spruce 155 understory. About half of the jack pine trees were dead before the fire and almost all black spruce trees were alive, resulting in an overall composition of 59\% black spruce. The fire was ignited using a ground-based Dackermin torch and resulted in a high-intensity crown fire (Figure $2 \mathrm{j}$ ) (Hvenegaard, 2017b).

2016 crown fire (CF 2016)

160 Crown fire on 30/06/2016 over 5-m-wide strip at stand of similar composition as the CF 2017 stand. The fire was ignited using a ground-based Dackermin torch and resulted in a high-intensity crown fire (Figure 2k) (Hvenegaard, 2017a).

Unburned jack pine-dominated site (Control S) and unburned black spruce-dominated site (Control S)

165 Control P is a jack-pine dominated stand with some shrubs, and a forest floor with needles, moss and lichen. Control S has predominant black spruce in the overstory (86\%) of which most was living (71\%), and in the understory (78\%) of which most was dead (67\%; Figure $2 \mathrm{i})$ (Hvenegaard, 2020).

\subsection{Sampling design and data collection}

170 We established 10 circular sample plots $\left(200 \mathrm{~m}^{2}\right)$ within 4 experimental sites affected by crown fires between 2015 and 2017, and 4 circular sample plots $\left(200 \mathrm{~m}^{2}\right)$ within 2 experimental sites 
affected by surface fires in 2015 and 2017 (Figure S1). Due to the small area burned $\left(\sim 100 \mathrm{~m}^{2}\right)$ in the 2018 surface fire, we used the whole experimental site as a sampling plot and the surrounding unburned area as a control for burned experimental sites dominated by jack pine (Figure S2). We 175 established 7 circular sample plots $\left(200 \mathrm{~m}^{2}\right)$ within undisturbed black spruce-dominated stands as controls for burned experimental sites dominated by black spruce (Figure S1).

\subsubsection{Vegetation biomass and necromass}

To estimate aboveground vegetation biomass, we measured basic tree characteristics (diameter at $1.3 \mathrm{~m}$ height and living crown length) in all sample plots. Living tree biomass calculations were done according to Lambert et al. (2005). All standing and down deadwood longer than $1.3 \mathrm{~m}$ and at least $10 \mathrm{~cm}$ in diameter were included as woody necromass. Woody necromass was calculated according to Lambert et al. (2005) for standing and down trees that still had their full length using model parameter estimates for wood and excluding bark, branches, and foliage. For dead wood fragments, we used mathematical formulas of a truncated cone. For understory biomass quantification, we destructively sampled 2 areas $\left(0.04 \mathrm{~m}^{2}\right)$ per sample plot. Understory biomass loads were separated into shrubs and ground vegetation (i.e. grasses, mosses and lichens). From the same locations, forest floor samples including litter and partly decomposed material were collected. All collected samples were dried at $60{ }^{\circ} \mathrm{C}$ to constant weight. When reporting biomass loads, biomass refers to living biomass and necromass refers to dead biomass.

\subsubsection{Soil properties}

Soil samples were obtained from one soil pit $(0.4 \times 0.4 \mathrm{~m})$, excavated at each sample plot, and taken horizontally using a cylindrical soil corer (6 cm diameter and $6 \mathrm{~cm}$ length). We sampled the organic layer (excluding plant and litter material, i.e. humic material) and the underlying mineral 
soil profile at $0-5$ and $25-30 \mathrm{~cm}$ depths. The organic humic layer depth was measured at three

195 walls of each excavated pit. Samples were oven-dried at $60{ }^{\circ} \mathrm{C}$ to constant weight and sieved to 2 mm. Soil pH was analyzed with a glass electrode (Standard pH meter, Radiometer Analytical, Lyon, France) in $35 \mathrm{~mL}$ soil suspensions at a 1:2.5 (v:v) ratio of soil to ultrapure Milli-Q water, left overnight to stand after mixing. Soil $\mathrm{C}$ and nitrogen $(\mathrm{N})$ contents were determined in ground samples by an elemental analyzer (Vario MAX CN, Elementar Analysensysteme GmbH, 200 Germany). Total soil C and N stocks in different soil horizons were calculated according to Hossain et al. (2015) using: i) the percent organic $\mathrm{C}$ and $\mathrm{N}$ from the elemental analyzer; ii) the bulk density $\left(\mathrm{g}\right.$ soil $\left.\mathrm{cm}^{3}\right)$ calculated using soil corer volume and soil samples' dry weight, and iii) the layer thickness. Samples used in the incubation experiment (section 2.3.3) were kept in cold bags during the field campaign and pre-incubated at $4{ }^{\circ} \mathrm{C}$.

205 Soil temperature (ST) and soil moisture (SM) were measured concurrently with $\mathrm{R}_{\mathrm{S}}$ (see section 2.3.3) approximately $20 \mathrm{~cm}$ away from each soil collar. ST was recorded from 5 and $10 \mathrm{~cm}$ depth $\left(\mathrm{ST}_{5}\right.$ and $\mathrm{ST}_{10}$, respectively) from the soil surface with an insulated Type $\mathrm{K}$ thermocouple connected with a Hobo data logger (Onset Computer Corporation). SM was recorded from $5 \mathrm{~cm}$ depth directly below the litter layer with a moisture sensor (Thetaprobe ML3, Delta-T Devices Ltd,

210 Cambridge, UK) connected to a data reader (HH2 moisture meter, Delta-T Devices Ltd, Cambridge, UK).

\subsubsection{Soil respiration}

Total soil surface $\mathrm{CO}_{2}$ efflux $\left(\mathrm{R}_{\mathrm{S}}\right)$ was measured in the field over 6 consecutive days between 9 AM to 4 PM using a portable dark chamber $(22 \mathrm{~cm}$ diameter and $24 \mathrm{~cm}$ height) placed on polyvinylchloride collars. As part of the portable chamber, an insulation rubber ensured a leakproof fit with the collars $(22 \mathrm{~cm}$ diameter and $5 \mathrm{~cm}$ height). To limit local disturbance, collars were 
inserted at a depth of $2 \mathrm{~cm}$ into the ground, avoiding root damage, and surrounded with sand. Neither the vegetation nor the litter was removed during the $R_{S}$ measurement. This is a wellestablished approach to measure $\mathrm{R}_{\mathrm{S}}$ in well-drained upland boreal soils where soil surface 220 irregularities are not as common as in boreal peat soils (Köster et al., 2017; Koster et al., 2018; Palviainen et al., 2018). Two collars were inserted in the center of each sample plot at least $3 \mathrm{~m}$ apart on the day before $R_{S}$ measurements, except in the control for pine-dominated sites and the site burned in 2018, where three pairs of collars were juxtaposed in three extremities of the burned plot (three inside burned area and three outside burned area) about $4 \mathrm{~m}$ away from each other as

225 soon as the soil surface cooled down (Figure $\mathrm{S} 2$ ). The $\mathrm{R}_{\mathrm{S}}$ measurements in the burned and control site were performed simultaneously in three occasions: 1 hour after the fire and on the second and third day after the fire.

The portable chamber was made of Plexiglas covered with aluminum foil and was equipped with a small fan $(2.5 \mathrm{~cm}$ diameter $)$ to mix the air inside. The $\mathrm{CO}_{2}$ concentration increase was measured with a non-dispersive infrared $\mathrm{CO}_{2}$ probe (GMP343, Vaisala Oyj, Finland) at $5 \mathrm{~s}$ intervals for 5 min. Relative humidity and temperature in the chamber were simultaneously measured with an HM70 sensor (Vaisala Oyj, Vantaa, Finland). $R_{S}$ in each collar was calculated from the linear fit of $\mathrm{CO}_{2}$ concentration increase inside the chamber headspace over the 5 min measurement period (Pumpanen et al., 2015).

$235 \mathrm{CO}_{2}$ flux rates from the humic and mineral layers were measured in a laboratory incubation experiment by adapting the procedure used by Riikonen et al. (2017). We used one soil sample per sample plot from each soil depth (i.e. humic layer, mineral layers at $0-5$ and $25-30 \mathrm{~cm}$ ). The samples were incubated in glass flasks $(500 \mathrm{ml})$ in a climate chamber (WEISS WK11 340, Weiss Klimatechnik, Germany) at $10{ }^{\circ} \mathrm{C}$ for $24 \mathrm{~h}$ with a water content similar to field conditions. Before 
240 incubation, visible roots were removed, samples were weighed, and glass flasks were flushed with $21 \% \mathrm{O}_{2}$ and $79 \% \mathrm{~N}_{2}$ technical air and sealed with rubber corks. For every three incubated soil samples, one empty flask was prepared similarly and used as a blank sample. After the incubation, a $50 \mathrm{ml}$ gas sample was taken from each flask with a $60 \mathrm{ml}$ polypropylene syringe, injected into 12 $\mathrm{ml}$ Exetainer vials and analyzed by an Agilent Gas Chromatograph 7890A (GC, Agilent 245 Technologies, USA) fitted with a Flame Ionization Detector (FID). Helium (45 $\mathrm{ml} \mathrm{min}^{-1}$ ) was the carrier gas while synthetic air $\left(450 \mathrm{ml} \mathrm{min}^{-1}\right)$ and hydrogen $\left(40 \mathrm{ml} \mathrm{min} \mathrm{m}^{-1}\right)$ were the flame gases, and $5 \mathrm{ml} \mathrm{min}-1$ of $\mathrm{N}_{2}$ was used as the make-up gas for the FID. The oven temperature was $60{ }^{\circ} \mathrm{C}$ and the detector temperature was $300{ }^{\circ} \mathrm{C}$. The mass of $\mathrm{CO}_{2}$ released from each soil sample per hour $\left(\mathrm{m}_{\mathrm{CO}_{2}}, \mu \mathrm{g} \mathrm{CO} \mathrm{g} \mathrm{soil}^{-1} \mathrm{~h}^{-1}\right)$ was calculated by eq. (1):

$250 \quad m_{\mathrm{CO}_{2}}=\frac{\left(C_{r}-C_{0}\right) M_{\mathrm{CO}_{2}} V_{i}}{t V_{m} m_{\text {soil }}}$

where $\mathrm{C}_{\mathrm{r}}\left(\mu \mathrm{g} \mathrm{g}^{-1}\right)$ is the $\mathrm{CO}_{2}$ concentration in each flask after incubation, $C_{0}\left(\mu \mathrm{g} \mathrm{g}^{-1}\right)$ is the $\mathrm{CO}_{2}$ concentration in the technical air, $M_{\mathrm{CO}_{2}}\left(\mathrm{~g} \mathrm{~mol}^{-1}\right)$ is the molecular mass of $\mathrm{CO}_{2}, V_{i}\left(\mathrm{~m}^{3}\right)$ is the volume of the glass flask, $t$ (hours) is the incubation duration, $V_{m}\left(\mathrm{~m}^{3} \mathrm{~mol}^{-1}\right)$ is the molar volume of a gas and $m_{\text {soil }}(\mathrm{g})$ is the mass of the incubated soil sample. Incubation $\mathrm{CO}_{2}$ flux rates $\left(\mathrm{m}_{\mathrm{CO}_{2}}\right)$ were scaled 255 to units of area $\left(\mathrm{g} \mathrm{CO}_{2} \mathrm{~m}^{2} \mathrm{~d}^{-1}\right)$ using the corresponding soil bulk density and horizon depths.

As nearly $95 \%$ of the soil surface $\mathrm{CO}_{2}$ fluxes represent the root $/$ microbial $\mathrm{CO}_{2}$ production in the soil subsurface (Risk et al., 2002), we divided $R_{S}$ into: (1) respiration from the incubated humus layer $\left(R_{H h}\right),(2)$ respiration from the incubated upper mineral layer $\left(0-5 \mathrm{~cm}\right.$ depth; $\left.R_{H 5}\right)$, and (3) residual respiration, which represents $\mathrm{CO}_{2}$ effluxes from roots and ground vegetation, and to a least extent from deeper mineral soils (O’Neill et al., 2006). The heterotrophic respiration component $\left(R_{H}\right)$ was calculated as the sum of $R_{H h}$ and $R_{H 5}$. To derive the autotrophic respiration component 
$\left(R_{A}\right)$, reflecting the residual respiration, the $R_{S}$ was adjusted to the incubation temperature used in this study according to the non-linear response of soil respiration to temperature given by eq. (2):

$R_{T 10}=R_{S} Q_{10}^{\frac{T_{10}-S T_{5}}{10}}$

265 where $R_{T 10}\left(\mathrm{~g} \mathrm{CO}_{2} \mathrm{~m}^{-2} \mathrm{~d}^{-1}\right)$ is the soil respiration adjusted to the incubation temperature, $T_{10}\left({ }^{\circ} \mathrm{C}\right)$ is the incubation temperature $\left(10{ }^{\circ} \mathrm{C}\right), \mathrm{ST}_{5}\left({ }^{\circ} \mathrm{C}\right)$ is the soil temperature measured at $5 \mathrm{~cm}$ depth to the nearest collar, and $Q_{10}$ is the temperature response coefficient of the respiration. The $Q_{10}$ was set to 2.5 as suggested for soil respiration (Köster et al., 2014; Wang et al., 2006). The $R_{A}$ was, therefore, calculated by eq. (3):

$270 \quad R_{A}=R_{T 10}-\left(R_{H h}+R_{H 5}\right)$

\subsection{Statistical analysis}

We assessed the effect of fire type on response variables at the experimental site level using regression analysis based on least squares estimates. The effect of fire type on soil respiration variables $\left(R_{A}\right.$ and $\left.R_{H}\right)$ was assessed separately for each dominant tree species according to eq. 4:

$275 \hat{y}=b_{0}+b 1_{S T 5}+b 2_{S M}+b 3_{\text {site }}+e$

where $\hat{y}$ was the predicted values of either $R_{H}$ or $R_{A}, S T_{5}$ was the soil temperature at $5 \mathrm{~cm}$ depth, SM was soil moisture, and site was the experimental site with 5 levels (control P, SF 2018, SF 2017, SF 2015, CF 2015 A and B) for pine-dominated sites and 3 levels (control S, CF 2017, and CF 2016) for spruce-dominated sites, $b_{0}$ was the intercept, $b_{1}, b_{2}, b_{3}$ were the slopes, and $e$ was the residual. The effect of fire type on $S T$ and on $S M$ was assessed separately for each dominant tree species according to eq. 5 : 
$\hat{y}=b_{0}+b 1_{\text {site }}+e$

where $\hat{y}$ was the predicted values of either soil temperature at $5 \mathrm{~cm}\left(S T_{5}\right)$ or $10 \mathrm{~cm}$ depth $\left(S T_{10}\right)$ or SM, site was the experimental site with 6 levels (control P, SF 2018, SF 2017, SF 2015, CF 2015 spruce-dominated sites, $b_{0}$ was the intercept, $b 1$ was the slope for each level of experimental site, and $e$ was the residual.

Model assumptions were checked using residual distributions. We used a natural $\log$ transformation on soil respiration variables to ensure homogeneity of variance. When experimental 290 site was significant, Tukey HSD all pairwise comparisons were conducted.

Since we only had one real treatment replicate (CF 2015 A and CF 2015 B), our experimental units are the experimental sites. This means that plots and collars inside each experimental site were dependent replicates. To deal with the dependency structure between repeated measurements inside the same plot which are from or near the same collar, mixed-effects models are usually used.

295 However, the small sample sizes of each experimental site in this study hinders the use of a multilevel model (Hox, 2010), making the linear regression a more adequate choice. All statistical analyses were performed with a significance level of $P<0.05$ using $\mathrm{R}$ (version 4.1.1, $R$ Core Team, 2021) and JMP Pro (version 14.1, SAS Institute Inc., 2021).

\section{Results}

\subsection{Vegetation biomass and necromass}

The pine-dominated control site (Control P) had a low tree density (1416 stems ha-1) and very little woody necromass (Figures $2 \& 3$ ). Most of its plant biomass was standing mature jack pine trees (Figure 2). The spruce-dominated control site (Control S) had a higher tree density (2271 stems ha- 
${ }^{1}$ ), partly composed of standing woody necromass, along with substantial down woody necromass 305 (Figures $2 \& 3$ ). Total living aboveground biomass was higher in both control sites than in the burned sites, whereas total woody necromass was lower (Figure 3).

Among all burned sites, only the one burned by a surface fire in that same year (i.e. 2018) had living trees at the time of the field measurements (Figure 3). Most of the dead trees were still standing in all sites at the time of measurements regardless of the fire type (Figures $2 \& 3$ ). Generally, burned sites had little or no moss biomass, but grass and shrubs were present in most sites at varying quantities (Figure 3). Within those, pine-dominated sites, except the one burned in 2018 by a surface fire (SF 2018), had larger understory plant biomass than spruce-dominated sites. A substantial amount of tree foliage (albeit dead) was still present in the site burned by surface fire in 2017 but not in the site burned by surface fire in 2015 (SF 2015; Figure 2).

\section{$315 \quad 3.2 \quad$ Soil properties}

Control S site was characterized by a much thinner humic layer depth $(2.6 \mathrm{~cm})$ compared to control $\mathrm{P}(6.1 \mathrm{~cm})$, and consequently lower total soil $\mathrm{C}$ and $\mathrm{N}$ stocks in the humic layer (Table 2 \& Figure S3a-d). The total soil $\mathrm{C}$ and $\mathrm{N}$ in the humic layer of control $\mathrm{P}$ were about one-third of those in control S (Figure S3a-d). The mean C stock in the humic layer of burned sites ranged from 1 to 1.6 $320 \mathrm{~kg} \mathrm{C} \mathrm{m}{ }^{-2}$, except in the site burned by a crown fire in 2015 (CF $2015 \mathrm{~B}$ ) where the mean C stock was only $0.56 \mathrm{~kg} \mathrm{C} \mathrm{m}^{-2}$. The mean $\mathrm{N}$ stock in the humic layer of the same site was also below $(20.2$ $\left.\mathrm{g} \mathrm{N} \mathrm{m}^{-2}\right)$ the range of observed mean total soil $\mathrm{N}\left(36.7-62.8 \mathrm{~g} \mathrm{~N} \mathrm{~m}^{-2}\right)$ in the other burned sites. The mean $\mathrm{C}$ stock in the mineral layer of fire-affected pine sites was generally higher at $0-5 \mathrm{~cm}$ (except in SF 2018) and lower at 25-30 cm than in control P, whereas in fire-affected spruce sites

325 an opposite trend was observed (Figure S3a-c). No distinguishable pattern in the mean N stock in the mineral layer of neither fire-affected pine nor spruce sites was observed (Figure S3e-f). 
The mean soil $\mathrm{pH}$ of all sites ranged from 7 to 8 and increased with soil depth (Figure S3g-i). Soil $\mathrm{pH}$ of the humic layer tended to be higher in the burned sites compared to unburned sites (Figure $\mathrm{S} 3 \mathrm{~g})$. Whereas most burned pine-dominated sites had higher mean soil $\mathrm{pH}$ in the mineral layer than control P, burned spruce-dominated sites tended to have lower mean soil $\mathrm{pH}$ than control $\mathrm{S}$ (Figure S3h-i).

There was a clear distinction in the distribution of the $\mathrm{ST}_{10}$ in the unburned (control) sites. In control $\mathrm{P}, \mathrm{ST}_{10}$ observations were mostly above the median $\left(12.6^{\circ} \mathrm{C}\right)$ of the unburned sites, while in control $\mathrm{S}, \mathrm{ST}_{10}$ observations were mostly below the median (Figure $4 \mathrm{a}$ ). After surface fires, the mean $\mathrm{ST}_{10}$ was significantly higher in the site burned in 2015 than in control P (Table 2). After crown fires in pine-dominated sites, the mean $\mathrm{ST}_{10}$ was significantly higher in the site burned in 2015 (B) than in control $\mathrm{P}$, whereas after crown fires in spruce-dominated sites, the mean $\mathrm{ST}_{10}$ was significantly higher in the sites burned in 2016 and in 2017 than in control S (Table 2).

There was no clear distinction in the distribution of the $\mathrm{ST}_{5}$ between control $\mathrm{P}$ and control $\mathrm{S}$ (Figure 4b). Within the burned sites, the range of $\mathrm{ST}_{5}$ varied by $7.1^{\circ} \mathrm{C}$ in crown fire-affected sites, and by $3.6^{\circ} \mathrm{C}$ in surface fire-affected sites (Figure $4 \mathrm{~b}$ ). After surface fires, the mean $\mathrm{ST}_{5}$ only differed from control P in the site burned in 2015 (SF 2015), where it was $2.3{ }^{\circ} \mathrm{C}$ higher (Table 2). In all pineand spruce-dominated sites burned by crown fires, the mean $\mathrm{ST}_{5}$ was significantly higher than in the unburned sites (Table 2).

In contrast, there was a clear distinction in the distribution of the SM between control P and control S (Figure 4c). In control P, SM observations were mostly below the median $(28.1 \%$ volumetric water content), while in control S, SM observations were mostly above the median (Figure 4c). At the pine sites, the sites burnt by surface fires had a similar mean SM than the control P (Table 2); however, all the sites burnt by crown fires had higher mean SM than the control P. At the spruce- 
dominated sites burnt by crown fires, the mean SM was either lower or did not change compared to control S (Table 2).

\subsection{Soil respiration}

The total $\mathrm{CO}_{2}$ efflux measured in the field $\left(\mathrm{R}_{\mathrm{S}}\right)$ ranged from 4.3 to $43.0 \mathrm{~g} \mathrm{CO}_{2} \mathrm{~m}^{-2} \mathrm{~d}^{-1}$, whereas the $\mathrm{CO}_{2}$ efflux adjusted to $10{ }^{\circ} \mathrm{C}\left(\mathrm{R}_{\mathrm{T} 10}\right)$ ranged from 1.5 to $24.9 \mathrm{~g} \mathrm{CO}_{2} \mathrm{~m}^{-2} \mathrm{~d}^{-1}$ (Figure $\left.5 \mathrm{a}-\mathrm{b}\right)$. The upper range values of the $\mathrm{CO}_{2}$ effluxes were from measurements performed immediately after the surface fire in 2018 (Figure 5a-b). The mean $\mathrm{R}_{\mathrm{A}}$ (i.e. residual respiration: $\mathrm{CO}_{2}$ efflux from roots, ground vegetation, and deeper mineral soils) was $8.97 \pm 4.69$ (standard deviation) $\mathrm{g} \mathrm{CO}_{2} \mathrm{~m}^{-2} \mathrm{~d}^{-1}$ in the unburned sites, $6.67 \pm 5.57 \mathrm{~g} \mathrm{CO}_{2} \mathrm{~m}^{-2} \mathrm{~d}^{-1}$ in the surface fire-affected sites, and $1.87 \pm 2.23 \mathrm{~g} \mathrm{CO}_{2}$ $\mathrm{m}^{-2} \mathrm{~d}^{-1}$ in crown fire-affected sites. After surface fires, the mean $\mathrm{R}_{\mathrm{A}}$ differed significantly only (lower) from control P in the site burned in 2015 (3 years after fire; Figure 6a). The site burned in 2018 (hours - days after fire) had the highest mean $\mathrm{R}_{\mathrm{A}}$ within sites burned by surface fires (Figure 6a). The response of $\mathrm{R}_{\mathrm{A}}$ to crown fires differed between pine- and spruce-dominated sites. In the fire-affected pine sites, $\mathrm{R}_{\mathrm{A}}$ did not differ from the control $\mathrm{P}$, whereas in fire-affected spruce sites, $R_{A}$ was significantly lower than in the control $S$ (Figure $6 a$ ). The percentage ratio of $R_{A}: R_{T 10}$, reflecting the contribution from roots, ground vegetation, and deeper mineral soils to total soil $\mathrm{CO}_{2}$ efflux, decreased following both surface and crown fires (Figure 6a). In the burned sites, the mean $\mathrm{R}_{\mathrm{A}}: \mathrm{R}_{\mathrm{T} 10}$ ratio was always lower than in unburned sites, averaging $48 \%$ and $37 \%$ in surface- and crown-fire affected sites, respectively.

The mean $R_{H h}\left(\mathrm{CO}_{2}\right.$ efflux measured at the humus layer) was $1.21 \pm 0.49$ (standard deviation) $\mathrm{g}$ $\mathrm{CO}_{2} \mathrm{~m}^{-2} \mathrm{~d}^{-1}$ in the unburned sites, $0.95 \pm 0.5 \mathrm{~g} \mathrm{CO}_{2} \mathrm{~m}^{-2} \mathrm{~d}^{-1}$ in crown fire-affected sites, and $1.54 \pm$ $0.28 \mathrm{~g} \mathrm{CO}_{2} \mathrm{~m}^{-2} \mathrm{~d}^{-1}$ in surface fire-affected sites. The mean $R_{H 5}\left(\mathrm{CO}_{2}\right.$ efflux measured at the $0-5$ cm mineral layer) was $1.08 \pm 0.29 \mathrm{~g} \mathrm{CO}_{2} \mathrm{~m}^{-2} \mathrm{~d}^{-1}$ in the unburned sites, $1.29 \pm 0.83 \mathrm{~g} \mathrm{CO}_{2} \mathrm{~m}^{-2} \mathrm{~d}^{-1}$ in 
crown fire-affected sites, and $2.1 \pm 0.25 \mathrm{~g} \mathrm{CO}_{2} \mathrm{~m}^{-2} \mathrm{~d}^{-1}$ in surface fire-affected sites. The mean $R_{H 30}$ $\left(\mathrm{CO}_{2}\right.$ efflux measured at the $25-30 \mathrm{~cm}$ mineral layer) was $0.97 \pm 0.12 \mathrm{~g} \mathrm{CO}_{2} \mathrm{~m}^{-2} \mathrm{~d}^{-1}$ in the 375 unburned sites, $0.95 \pm 0.42 \mathrm{~g} \mathrm{CO}_{2} \mathrm{~m}^{-2} \mathrm{~d}^{-1}$ in crown fire-affected sites, and $1.70 \pm 0.72 \mathrm{~g} \mathrm{CO}_{2} \mathrm{~m}^{-2}$ $\mathrm{d}^{-1}$ in the surface fire-affected sites. After surface fires, the mean $R_{H}$ (i.e., the sum of $R_{H h}$ and $R_{H 5}$ ) in the site burned in 2018 (hours - days after fire) was significantly higher than in control P, whereas the other sites had similar $\mathrm{R}_{\mathrm{H}}$ (Figure $6 \mathrm{~b}$ ). The response of $\mathrm{R}_{\mathrm{H}}$ to crown fires also differed between pine- and spruce-dominated sites, but in the opposite direction than $\mathrm{R}_{\mathrm{A}}$. In the fire-affected pine sites, $\mathrm{R}_{\mathrm{H}}$ was significantly lower than in control $\mathrm{P}$, whereas in the fire-affected spruce sites, $\mathrm{R}_{\mathrm{H}}$ was similar to control $\mathrm{S}$ (Figure $6 \mathrm{~b}$ ). The percentage ratio of $\mathrm{R}_{\mathrm{H}}: \mathrm{R}_{\mathrm{T} 10}$, reflecting the contribution from decomposition in the humic and mineral $\left(0-5 \mathrm{~cm}\right.$ depth) layers to total soil $\mathrm{CO}_{2}$ efflux, increased following both surface and crown fires (Figure 6b).

\section{Discussion}

$385 \quad 4.1 \quad$ Fire types and associated tree mortality

Between 1 and 3 years after fire, only one of the burned sites had living trees, indicating that all but one of the experimental fires examined were stand-replacing within this timeframe, irrespective of fire type. Most of the trees in the site burned in 2018 had not died by 2021, thus this site represented the only non-stand-replacing fire in this study. Stand replacement following either type of fire is an important natural process for the vegetation and $\mathrm{C}$ dynamics of boreal forests (Bond \& Keeley, 2005). While crown fires kill the trees immediately by directly combusting their crowns, surface fires can kill the trees through tissue necrosis from heat transfer (Michaletz \& Johnson, 2007). The heat lethality is determined by the interaction of the tree functional traits and fire characteristics (e.g. intensity and temperature residence time) (Bär et al., 2019). Tree mortality and 395 potentially entire stand mortality may occur after surface fires when, for instance, dry fuel and 
weather conditions lead to higher fire intensities and higher associated impacts on vegetation and soil (McRae et al., 2006). The sites burned by surface fires had lower tree density and surface fuels in comparison to experimental sites burned by crown fires, thereby mimicking stands where surface fires tend to occur naturally (Wirth, 2005). Although all experimental surface fires had substantially lower estimated intensities than the experimental crown fires, the numeric ratings of fire intensity from the Canadian Forest FWI system (initial spread index (ISI), buildup index (BUI), and FWI) of the surface fires were within the range of the crown fires, except the 2018 surface fire (Table 1). Since these ratings reflect fire spread and fuel moisture, we can infer that the weather conditions had not been conducive to high-intensity fires at the time of the experimental fire in 2018 .

405 Jack pine and black spruce, the dominant tree species in our sites, are both fire embracers. They are adapted to promote high-intensity crown fires and quickly regenerate from seeds after the fire event, rather than to survive fire (Johnstone et al., 2010). In contrast, scots pine (Pinus sylvestris L.) and larch (Larix spp.), which dominate Eurasian boreal forests, are fire resisters, able to survive low- and medium-intensity surface fires due to traits such as self-pruning, high leaf moisture, and 410 thick bark (Wirth, 2005). Due to the overlap between fire resister trees and a higher proportion of surface fires (e.g. $~ 80 \%$ in Siberia, (Conard \& Ivanova, 1997)), fire-induced tree mortality can be as low as 20\% in the boreal Eurasia (Ryan, 2002; Wirth, 2005). In North America, however, standreplacing crown fires are predominant, as most conifers are fire embracers (Rogers et al., 2015). As a result, surface fires represent only $10 \%$ of fires in North American boreal forests (Wirth, 415 2005). With most tree species studied here being thin-barked, stand survival would only occur when surface fires were patchy or of low intensity (Wirth, 2005), as it was the case for the surface fire in 2018 .

\subsection{Fire types and soil properties}


Nearly all experimental sites in this study experienced stand-replacing fires, but differences in ST and SM between burned and unburned sites were greater after crown fires. All sites burned by crown fires had higher ST (most of them down to $10 \mathrm{~cm}$ ), which could be explained by the increase in incoming solar radiation due to the lack of canopy foliage, and the reduction of the insulating moss and soil organic layer, and in surface albedo (Hart et al., 2005). Regarding SM, within the sites burned by crown fires, spruce-dominated sites had either lower or equal values compared to 425 unburned spruce sites, whereas pine-dominated sites had higher SM. Recently burned forests tend to have lower SM due to an increase in soil evaporation despite a decrease in plant transpiration and canopy evaporation (Bond-Lamberty et al., 2009). It was, therefore, surprising to observe higher SM in the pine sites burned by crown fires.

Since surface fires do not combust the overstory canopy and do not immediately kill the trees, 430 changes in temperature and moisture shortly after fire supposedly occur mostly through fire impacts on the understory and the forest floor. We did not detect changes in either SM or ST in the first 3 days after the surface fire, which combined with the inferences based on vegetation mortality, suggests that the low-intensity surface fire had low severity also belowground. The surface fire in the site burned in 2018 was, however, extinguished with water, thus, our measurements of SM and

435 ST taken within 3 days after the fire were not representative of natural soil conditions immediately after the fire. The only fire effect on the studied soil properties in the other sites burned by surface fires was in the one burned in 2015 , where ST was significantly higher down to $10 \mathrm{~cm}$. This may have reflected the lower canopy coverage compared to the site burned in 2017 rather than a higher soil burn severity, as all surface fires lost equally $\sim 30 \%$ of their humic layer.

$440 \quad 4.3 \quad$ Fire types and total soil surface $\mathrm{CO}_{2}$ efflux $\left(\mathrm{R}_{\mathrm{S}}\right)$ 
The variation in the chamber-based $R_{S}$ in the studied sites experimentally burned by surface fires was greater than in sites burned by crown fires due to the high $\mathrm{CO}_{2}$ effluxes recorded immediately after the non-stand-replacing fire in 2018, which were almost entirely above the median $\mathrm{CO}_{2}$ efflux including all 3 studied sites affected by experimental surface fires. The $\mathrm{R}_{\mathrm{S}}$ measurements conducted 445 immediately after the non-stand-replacing surface fire in 2018 ranged from 9.7 to $43 \mathrm{~g} \mathrm{CO}_{2} \mathrm{~m}^{-2} \mathrm{~d}^{-}$ 1. This is substantially higher than the mean $\mathrm{CO}_{2}$ efflux $\left(3.4 \mathrm{~g} \mathrm{CO}_{2} \mathrm{~m}^{-2} \mathrm{~d}^{-1}\right)$ registered immediately after a prescribed low-intensity surface fire in a larch forest in China (Hu et al., 2016). Conversely, our measurements of the $\mathrm{R}_{\mathrm{S}}\left(6.5\right.$ to $\left.20.8 \mathrm{~g} \mathrm{CO}_{2} \mathrm{~m}^{-2} \mathrm{~d}^{-1}\right) 1-3$ years after the stand-replacing surface fires were close to mean $\mathrm{CO}_{2}$ effluxes measured $4\left(15.7 \mathrm{~g} \mathrm{CO}_{2} \mathrm{~m}^{-2} \mathrm{~d}^{-1}\right)$ and 5 years $\left(4.1 \mathrm{~g} \mathrm{CO}_{2} \mathrm{~m}^{-2}\right.$ $450 \mathrm{~d}^{-1}$ ) recorded after stand-replacing surface fires in larch forests in eastern Siberia (Sawamoto et al., 2000; Takakai et al., 2010). The $\mathrm{R}_{\mathrm{S}}$ measurements in the sites experimentally burned by standreplacing crown fires ranged from 4.3 to $16.7 \mathrm{~g} \mathrm{CO}_{2} \mathrm{~m}^{-2} \mathrm{~d}^{-1}$, which is within the range of mean $\mathrm{CO}_{2}$ efflux $\left(0.6-22 \mathrm{~g} \mathrm{CO}_{2} \mathrm{~m}^{-2} \mathrm{~d}^{-1}\right)$ measured $0-5$ years after crown fires conducted in studies of the North American boreal forests (Ribeiro-Kumara et al., 2020). For instance, $3.2 \mathrm{~g} \mathrm{CO}_{2} \mathrm{~m}^{-2} \mathrm{~d}^{-1} 2$ 455 years after fire in black spruce in interior Alaska (O'Donnell et al., 2008), $22 \mathrm{~g} \mathrm{CO}_{2} \mathrm{~m}^{-2} \mathrm{~d}^{-1} 3$ years after fire in black spruce near Eagle Plains, Canada (Köster et al., 2017), and $5.1 \mathrm{~g} \mathrm{CO}_{2} \mathrm{~m}^{-2} \mathrm{~d}^{-1} 2$ years after fire in black spruce and $3.7 \mathrm{~g} \mathrm{CO}_{2} \mathrm{~m}^{-2} \mathrm{~d}^{-1} 5$ years after fire in jack pine in Manitoba, Canada (Burke et al., 1997).

\subsection{Fire types and soil autotrophic respiration $\left(\mathrm{R}_{\mathrm{A}}\right)$}

460 Fire is an important driver of change for the $\mathrm{C}$ dynamics in boreal forests, especially when causing stand-replacement. A stand-replacing fire changes the quantity and/or quality of the living and dead $\mathrm{C}$ pools above- and belowground, and therefore, also the $\mathrm{C}$ exchange of the stand (Kurz et al., 2013). A period of net $\mathrm{C}$ loss, negative net ecosystem production (NEP), is introduced by the fire 
impact on the vegetation and soils (Kurz et al., 2013). Boreal forests generally recover their net C 465 uptake, positive NEP, about 10 years after fire, with this recovery strongly driven by the postfire recovery of plant biomass (Hicke et al., 2003; Mack et al., 2008). Changes in C allocation, between biomass production and (root and foliar) respiration, throughout vegetation reestablishment has a critical role in the atmosphere-land $\mathrm{C}$ exchange following fire. Root respiration originates from an internal $\mathrm{C}$ storage pool comprised of $\mathrm{C}$ fixed up to several years in the past and from recent 470 photosynthates with a days-to-weeks lag, and is a major component of the soil autotrophic respiration (Czimczik et al., 2006; Högberg et al., 2001; Pumpanen et al., 2015).

We hypothesized that the soil autotrophic respiration, here represented by $\mathrm{R}_{\mathrm{A}}$, would decrease sooner and more drastically after crown fires (i.e. higher instant tree mortality) than after surface fires (i.e. lower and delayed tree mortality). We indeed detected a 4-fold decrease in $\mathrm{R}_{\mathrm{A}} 1-2$ years 475 after crown fires and a 2-fold decrease in $\mathrm{R}_{\mathrm{A}} 3$ years after surface fires. We did not have the opportunity to measure $\mathrm{R}_{\mathrm{A}}$ immediately after a crown fire but based on the drastic $\mathrm{R}_{\mathrm{A}}$ decrease observed 1 year after a crown fire when already some understory vegetation had recovered, an even larger decrease in $\mathrm{R}_{\mathrm{A}}$ immediately after a crown fire could be expected. Meanwhile, we did not detect a significant decrease in $\mathrm{R}_{\mathrm{A}}$ immediately after the non-stand-replacing surface fire. We, 480 therefore, attribute the decrease in $\mathrm{R}_{\mathrm{A}}$ postfire to the stand-replacing nature of all but one of the fires studied here.

The stand-replacing surface fires studied here killed the trees within $1-3$ years (probably even earlier than 1 year). This result is slightly lower compared to the general postfire tree mortality time ( $2-5$ years) documented for a series of low-intensity experimental burns that occurred over 485 a decade in a ponderosa pine (Pinus ponderosa Dougl.) forest aged $\sim 74-85$ years (Swezy \& Agee, 1991). In Swezy and Agee (1991), tree mortality was associated to the fine-root sensitivity to 
burning temperatures above $60^{\circ} \mathrm{C}$ exceeding a 5 -h burning period on the soil surface. Root necrosis might occur even at temperatures below $60{ }^{\circ} \mathrm{C}$ provided there was enough heating duration, thus roots are more likely to die when the soil organic layer burns for long periods through smoldering (Bär et al., 2019; Hart et al., 2005; Michaletz \& Johnson, 2007). The duration at which heating temperature remained above $300{ }^{\circ} \mathrm{C}$ at the forest floor during the most intense surface fire (SF 2017) was below $5 \mathrm{~min}$ on average (and $30 \mathrm{~min}$ on average for $60^{\circ} \mathrm{C}$ ), with all other examined fires scoring even lower heating durations (Table 1). Moreover, any smoldering was extinguished and substantial changes in the humus layer depth were not observed between sites burned by standreplacing surface fires and non-stand-replacing surface fires. Other non-smoldering fires, for instance in the same study site and in a Scots pine forest did not greatly affect the soil at a depth of $5 \mathrm{~cm}$ due to the absence of smoldering or ground fire at the soil subsurface (Kohli, 2021; Santín et al., 2016). It is, therefore, more likely that the surface fires killed trees mostly through stem necrosis in this study. Despite the stand-replacing surface fires studied here killing most trees within 1 year, we observed that $\mathrm{R}_{\mathrm{A}}$ had not significantly decreased during this period in relation to control. This could be due to the incompletion of the heat-induced girdling, allowing some parts of the phloem to be active, or to $\mathrm{C}$ reserves still being available 1 year after fire.

Regarding crown fires, one unanticipated finding was that, although $\mathrm{R}_{\mathrm{A}}$ significantly decreased 1 and 2 years after fire in spruce-dominated sites, $\mathrm{R}_{\mathrm{A}}$ did not differ from control in pine-dominated sites 3 years after fire. We were not able to measure $R_{A} 1-2$ years after crown fires in pinedominated sites, or $\mathrm{R}_{\mathrm{A}} 3$ years after crown fires in spruce-dominated sites. This result could, thus, be attributed to the time after the fire and associated understory recovery since our $R_{A}$ included $\mathrm{CO}_{2}$ efflux of the understory vegetation in addition to overstory tree roots. The experimental fires studied here were as severe in terms of tree mortality in the spruce- and pine-dominated sites, but 
510 we observed differences in the postfire regeneration of the understory. Although the understory vegetation is usually killed by even low-intensity surface fires (Dzwonko et al., 2018), the vascular portion regenerates quickly afterward, becoming temporarily the main living component after stand-replacing fires (Seedre et al., 2011). Here, grasses and shrubs in the understory strata in pinedominated sites showed signs of quicker regeneration than in spruce-dominated sites, while the moss and lichen layer remained mostly absent even 3 years after fire. For comparison, the moss layer in a black spruce forest in western Canada took over 4 decades to recover to prefire levels, whereas the vascular plants recovered in half that time (Köster et al., 2017). It is also possible that the crown fires in the spruce-dominated sites burned proportionally deeper into the soil ( $\sim 50 \%$ humic layer loss observed here) compared to the surface fires and at least to one of the crown fires

520 (CF 2015 A) in the pine-dominated sites, damaging the seedbed and consequently hampering vascular plants' regeneration. For instance, understory regeneration in the first 3 years after the fire in a Scots pine forest was associated with the burn severity of the forest floor (Dzwonko et al., 2018). According to the authors, vascular plants regenerated in lightly to moderately burned forest floor from buried seeds and buds, whereas in severely burned forest floors, regeneration relied on 525 dispersion.

The contribution from $\mathrm{R}_{\mathrm{A}}$ to total soil $\mathrm{CO}_{2}$ efflux in our unburned sites $(\sim 70 \%$ in control $\mathrm{P}$ and $\mathrm{S})$ was somewhat lower (88\%; O’Neill et al., 2006) and substantially lower ( $\sim 39 \%$ upper range; BondLamberty et al., 2004) than that estimated in black spruce forests of comparable age. In the latter study, autotrophic respiration only included root respiration and may also have been underestimated by $5-10 \%$, which might decrease the difference between our results. The contribution from $\mathrm{R}_{\mathrm{A}}$ to total soil $\mathrm{CO}_{2}$ efflux decreased after both fire types, averaging at $48 \%$ and $37 \%$ in surface and crown fire-affected sites, respectively. These results, although moderately 
higher, corroborate earlier findings that the proportion of autotrophic respiration is lower in the short-term ( $1-4$ years) after fire in spruce and pine forests $(-25-25 \%$; Bond-Lamberty et al., 2004; O’Neill et al., 2006; Song et al., 2019).

\subsection{Fire types and soil heterotrophic respiration $\left(\mathrm{R}_{\mathrm{H}}\right)$}

The mean $\mathrm{CO}_{2}$ efflux in the humus layer of the sites affected by crown fires $\left(0.95 \mathrm{~g} \mathrm{CO}_{2} \mathrm{~m}^{-2} \mathrm{~d}^{-1}\right)$ in our study was within the range of soil heterotrophic respiration observed in the short-medium term after high-intensity crown fires in North America. For example, $1.83 \mathrm{~g} \mathrm{CO}_{2} \mathrm{~m}^{-2} \mathrm{~d}^{-1}$ less than 5401 year after fire, $1.75 \mathrm{~g} \mathrm{CO}_{2} \mathrm{~m}^{-2} \mathrm{~d}^{-1} 4$ years after fire, and $0.26 \mathrm{~g} \mathrm{CO}_{2} \mathrm{~m}^{-2} \mathrm{~d}^{-1} 5$ years after fire, all in Canadian boreal forests (Bond-Lamberty et al., 2004; Czimczik et al., 2006). The mean $\mathrm{CO}_{2}$ efflux in the humus layer of the sites affected by the surface fires $\left(1.54 \mathrm{~g} \mathrm{CO}_{2} \mathrm{~m}^{-2} \mathrm{~d}^{-1}\right)$ studied here, although slightly higher than in crown fire-affected sites, was lower than the mean efflux (4.14 g $\left.\mathrm{CO}_{2} \mathrm{~m}^{-2} \mathrm{~d}^{-1}\right) 1$ year after a low-severity surface fire in Siberia, and the mean efflux $\left(5.27 \mathrm{~g} \mathrm{CO}_{2} \mathrm{~m}^{-2}\right.$

$\left.545 \mathrm{~d}^{-1}\right) 5$ years after a high-severity surface fire in Siberia (Sawamoto et al., 2001). The lower values observed here were partly due to the sampling of the humus layer rather than the whole forest floor.

We hypothesized that soil heterotrophic respiration, represented here by $R_{H}$ (i.e., the sum of $\mathrm{CO}_{2}$ efflux form the humus and $0-5 \mathrm{~cm}$ depth mineral layer), would not increase in the short-medium term after either surface or crown fires due to reported negative fire effects on soil decomposers 550 and soil organic matter decomposability (Holden et al., 2015; Köster et al., 2021; Köster et al., 2014). This was the case for $R_{H}$ in most of the burned sites, however, $R_{H}$ was significantly higher immediately after the 2018 non-stand-replacing surface fire. None of the main abiotic drivers of $R_{H}(\mathrm{ST}, \mathrm{SM}$, soil $\mathrm{pH})$ significantly changed after the non-stand-replacing surface fire, indicating that other factors may be driving the change in $R_{H}$. Inputs of both labile $\mathrm{C}$ and nutrients from ash and pyrogenic organic matter can affect the dynamics controlling soil decomposition by stimulating 
microbial activity (Maestrini et al., 2015; Sanchez-Garcia et al., 2021). The stimulating effect of ash deposition is transient — substantial amounts of ash may be easily removed by water and wind erosion and rapidly assimilated by microbes and plants (Cerdà \& Doerr, 2008; Holden et al., 2015) — and may be observed within days after deposition/application (Bang-Andreasen et al., 2021). While ash is generally positively related to increases in both $R_{S}$ and microbial activity, other factors such as SM and fire severity also affect these responses (Bodí et al., 2014; Fritze et al., 1994; Pereira et al., 2012). For instance, artificial wetting of experimentally burned African savannah soils followed by the addition of ash caused a brief but significantly higher $R_{H}$ pulse compared to wetted soils without ash (Sanchez-Garcia et al., 2021). Similarly, a Scots pine forest experienced an $R_{H}$ pulse after wetting and ash addition, although in this case ash was added to unburned soils (Fritze et al., 1994). It is possible, therefore, that the wetting performed to suppress the surface fire also contributed to the higher $R_{H}$ observed here.

\section{Conclusions}

This study assessed the short- to medium-term effects of fire type on soil C fluxes of mixed jack

570 pine and black spruce forest stands in Canada. In summary, this study shows that both fire types can alter $\mathrm{C}$ fluxes in the short- to medium-term through changes in vegetation and the soil environment. Confirming our first hypothesis, soil autotrophic respiration, represented here by the $\mathrm{CO}_{2}$ from tree roots, mycorrhiza, and the regenerating ground vegetation, decreased in sites affected by both crown and surface fires. In crown fire affected sites, autotrophic respiration was

575 lower for at least $1-2$ years after fire, whereas in surface fire affected sites, the decrease in autotrophic respiration was only significant 3 years after fire. In general, therefore, the instant tree mortality caused by crown fires drove the faster decrease in autotrophic respiration, whereas delayed mortality caused by surface fires delayed it. Contrary to our second hypothesis, however, 
soil heterotrophic respiration in the humic and mineral layer $(0-5 \mathrm{~cm}$ depth $)$ increased 580 immediately after the non-stand-replacing surface fire, possibly due to an agent (or combination of agents) not measured in this study. Therefore, future research could determine (1) whether the duration of the heterotrophic $\mathrm{CO}_{2}$ pulse following a non-stand-replacing surface fire is due to the interaction between ash and soil moisture, and (2) whether the soil $\mathrm{CO}_{2}$ flux differ in the short- to medium-term between stand-replacing surface and crown fires.

\section{Acknowledgements}

The authors would like to thank the Government of Northwest Territories for the experimental infrastructure, the technical staff of FPInnovations Wildfire Operations Research for assistance with field work, the EU COST Action (FireLinks - CA18135) "Fire in the Earth System: Science \& Society" for facilitating initial discussions that led to this study, and the anonymous reviwers and the editor for their valuable feedback. This research was supported by The Academy of Finland (project numbers 294600, 307222, and 327198) and Leverhulme Trust Research Grant (RPG-2014-095). CS received funding from the "Ramón y Cajal" research fellowship (RYC2018025797-I).

\section{References}

595 Alexander, M. E., Stefner, C. N., Mason, J. A., Stocks, B. J., Hartley, G. R., Maffey, M. E., Wotton, B. M., Taylor, S. W., Lavoie, N., \& Dalrymple, G. N. (2004). Characterizing the jack pine - black spruce fuel complex of the International Crown Fire Modelling Experiment (ICFME).

Bang-Andreasen, T., Peltre, M., Ellegaard-Jensen, L., Hansen, L. H., Ingerslev, M., Ronn, R., 600 Jacobsen, C. S., \& Kjoller, R. (2021). Application of wood ash leads to strong vertical gradients in soil $\mathrm{pH}$ changing prokaryotic community structure in forest top soil. Sci Rep, 11(1), 742. https://doi.org/10.1038/s41598-020-80732-0 
Bär, A., Michaletz, S. T., \& Mayr, S. (2019). Fire effects on tree physiology. New Phytol, 223(4), 1728-1741. https://doi.org/10.1111/nph.15871

605 Baxter, G. (2015). Effectiveness of stand-cleaning as a forest fuel treatment: observations in a Jack Pine stand at the Fort Providence Research Site. https://wildfire.fpinnovations.ca/102/Plot_C-3_Final_v4.pdf

Baxter, G., \& Sharpe, M. (2017). Underburning NWT August 2017. Technical report no. 59. https://wildfire.fpinnovations.ca/17/TR2017N59.pdf

610 Bodí, M. B., Martin, D. A., Balfour, V. N., Santín, C., Doerr, S. H., Pereira, P., Cerdà, A., \& Mataix-Solera, J. (2014). Wildland fire ash: Production, composition and eco-hydrogeomorphic effects. Earth-Science Reviews, 130, 103-127. https://doi.org/10.1016/i.earscirev.2013.12.007

Bond-Lamberty, B. E. N., Peckham, S. D., Gower, S. T., \& Ewers, B. E. (2009). Effects of fire on 615 regional evapotranspiration in the central Canadian boreal forest. Global Change Biology, 15(5), 1242-1254. https://doi.org/10.1111/j.1365-2486.2008.01776.x

Bond-Lamberty, B. E. N., Wang, C., \& Gower, S. T. (2004). Contribution of root respiration to soil surface CO2 flux in a boreal black spruce chronosequence. Tree Physiology, 24.

Bond, W. J., \& Keeley, J. E. (2005). Fire as a global 'herbivore': the ecology and evolution of 620 flammable ecosystems. Trends Ecol Evol, 20(7), 387-394. https://doi.org/10.1016/j.tree.2005.04.025

Burke, R. A., Zepp, R. G., Tarr, M. A., Miller, W. L., \& Stocks, B. J. (1997). Effect of fire on soilatmosphere exchange of methane and carbon dioxide in Canadian boreal forest sites. Journal of Geophysical Research: Atmospheres, 102(D24), 29289-29300. https://doi.org/10.1029/97jd01331

Burton, P. J., Messier, C., Weetman, G. F., Prepas, E. E., Adamowicz, W. L., \& Tittler, R. (2003). The current state of boreal forestry and the drive for change. In P. J. Burton, C. Messier, D. W. Smith, \& W. L. Adamowicz (Eds.), Towards Sustainable Management of the Boreal Forest (pp. 1-40). NRC Research Press.

630 Campbell, J. L., Fontaine, J. B., \& Donato, D. C. (2016). Carbon emissions from decomposition of fire-killed trees following a large wildfire in Oregon, United States. Journal of Geophysical Research: Biogeosciences, 121(3), 718-730. https://doi.org/10.1002/2015jg003165 
Canadian Climate Normals. (2021). Retrieved 22-12-2021 from https://climate.weather.gc.ca/climate normals/index e.html

635 Cerdà, A., \& Doerr, S. H. (2008). The effect of ash and needle cover on surface runoff and erosion in the immediate post-fire period. Catena, 74(3), 256-263. https://doi.org/10.1016/j.catena.2008.03.010

Conard, S. G., \& Ivanova, G. A. (1997). Wildfire in Russian boreal forests - potential impacts of fire regime characteristics on emissions and global carbon balance estimates. Environmental Pollution, 98(3), 305-313. https://doi.org/10.1016/S0269-7491(97)00140-1

Czimczik, C. I., Trumbore, S. E., Carbone, M. S., \& Winston, G. C. (2006). Changing sources of soil respiration with time since fire in a boreal forest. Global Change Biology, 12(6), 957971. https://doi.org/10.1111/j.1365-2486.2006.01107.x

de Groot, W. J., Flannigan, M. D., \& Cantin, A. S. (2013). Climate change impacts on future boreal 645 fire regimes. Forest Ecology and Management, 294, 35-44. https://doi.org/10.1016/j.foreco.2012.09.027

Dzwonko, Z., Loster, S., \& Gawroński, S. (2018). Effects of fire severity on understory community regeneration and early succession after burning of moist pine forest. Tuexenia, 197-214. https://doi.org/10.14471/2018.38.003

https://www.arcgis.com/home/item.html?id=10df2279f9684e4a9f6a7f08febac2a9

Fritze, H., Smolander, A., Levula, T., Kitunen, V., \& Mälkönen, E. (1994). Wood-ash fertilization and fire treatments in a Scots pine forest stand: Effects on the organic layer, microbial biomass, and microbial activity. Biology and Fertility of Soils, 17(1), 57-63. https://doi.org/10.1007/bf00418673

Gonzalez-Perez, J. A., Gonzalez-Vila, F. J., Almendros, G., \& Knicker, H. (2004). The effect of fire on soil organic matter--a review. Environ Int, 30(6), 855-870. https://doi.org/10.1016/i.envint.2004.02.003

Hart, S. C., DeLuca, T. H., Newman, G. S., MacKenzie, M. D., \& Boyle, S. I. (2005). Post-fire 660 vegetative dynamics as drivers of microbial community structure and function in forest soils. Forest Ecology and Management, 220(1-3), 166-184. https://doi.org/10.1016/j.foreco.2005.08.012 
Hicke, J. A., Asner, G. P., Kasischke, E. S., French, N. H. F., Randerson, J. T., Collatz, G. J., Stocks, B. J., Tucker, C. J., Los, S. O., \& Field, C. B. (2003). Postfire response of North 665 American boreal forest net primary productivity analyzed with satellite observations. Global Change Biology, 9, 1145-1157.

Högberg, P., Nordgren, A., Buchmann, N., Taylor, A., Ekblad, A., Högberg, M., Nyberg, G., Ottosson-Löfvenius, M., \& Read, D. (2001). Large-scale forest girdling shows that current photosynthesis drives soil respiration. Nature, 411.

670 Holden, S. R., Berhe, A. A., \& Treseder, K. K. (2015). Decreases in soil moisture and organic matter quality suppress microbial decomposition following a boreal forest fire. Soil Biology and Biochemistry, 87, 1-9. https://doi.org/10.1016/j.soilbio.2015.04.005

Hossain, M. F., Chen, W., \& Zhang, Y. (2015). Bulk density of mineral and organic soils in the Canada's arctic and sub-arctic. Information Processing in Agriculture, 2(3-4), 183-190. https://doi.org/10.1016/j.inpa.2015.09.001

Hox, J. J. (2010). Sample Sizes and Power Analysis in Multilevel Regression. In Multilevel Analysis: Techniques and Applications (Second edition ed.).

Hu, H., Hu, T., \& Sun, L. (2016). Spatial heterogeneity of soil respiration in a Larix gmelinii forest and the response to prescribed fire in the Greater Xing'an Mountains, China. Journal of Forestry Research, 27(5), 1153-1162. https://doi.org/10.1007/s11676-016-0215-4

Hvenegaard, S. (2017a). Fire Behaviour in Jack Pine/Black Spruce Forest Fuels following Mulch Fuel Treatments: A Case Study at the Canadian Boreal Community FireSmart Project. Technical report no. 24.

Hvenegaard, S. (2017b). Firebrand Transfer and Spot Fire Propagation: Observations from an 685 Experimental Fire at the Canadian Boreal Community FireSmart Project. Technical report no. 58. https://wildfire.fpinnovations.ca/171/TR2017N58.pdf

Hvenegaard, S. (2020). Fuel amendment as a forest fuel removal treatment: Exploratory trials in black spruce fuels at the fort providence wildfire experimental site. Technical report no. N21. https://wildfire.fpinnovations.ca/190/TR2020N21.pdf

690 Johnstone, J. F., Chapin, F. S., Hollingsworth, T. N., Mack, M. C., Romanovsky, V., \& Turetsky, M. (2010). Fire, climate change, and forest resilience in interior AlaskaThis article is one of a selection of papers from The Dynamics of Change in Alaska's Boreal Forests: 
Resilience and Vulnerability in Response to Climate Warming. Canadian Journal of Forest Research, 40(7), 1302-1312. https://doi.org/10.1139/x10-061

695 Kapcak, E. (2015). Assessing firebrand collection methodologies. Final report. https://wildfire.fpinnovations.ca/171/FireBrandCollectionMethodologiesNWTReportfinal. $\underline{\mathrm{pdf}}$

Kasischke, E. S. (2000). Boreal Ecosystems in the Global Carbon Cycle. In E. S. Kasishcke \& J. B. Stocks (Eds.), Fire, climate change, and carbon cycling in the boreal forest (Vol. 138, pp. 461). Springer-Verlag.

Kohli, J. (2021). Short term effects of an experimental surface fire on soil properties and soil surface CO2 fluxes in a Pinus sylvestris forest in southern-Finland.

[Master's thesis, HELDA University of Helsinki. http://urn.fi/URN:NBN:fi:hulib-202106183184 Köster, E., Köster, K., Berninger, F., Aaltonen, H., Zhou, X., \& Pumpanen, J. (2017). Carbon dioxide, methane and nitrous oxide fluxes from a fire chronosequence in subarctic boreal forests of Canada. Sci Total Environ, 601-602, 895-905. https://doi.org/10.1016/j.scitotenv.2017.05.246

Koster, E., Koster, K., Berninger, F., Prokushkin, A., Aaltonen, H., Zhou, X., \& Pumpanen, J. (2018). Changes in fluxes of carbon dioxide and methane caused by fire in Siberian boreal forest with continuous permafrost. $J$ Environ Manage, 228, 405-415. https://doi.org/10.1016/j.jenvman.2018.09.051

Köster, K., Aaltonen, H., Berninger, F., Heinonsalo, J., Köster, E., Ribeiro-Kumara, C., Sun, H., Tedersoo, L., Zhou, X., \& Pumpanen, J. (2021). Impacts of wildfire on soil microbiome in Boreal environments. Current Opinion in Environmental Science \& Health, 100258. https://doi.org/10.1016/j.coesh.2021.100258

Köster, K., Berninger, F., Lindén, A., Köster, E., \& Pumpanen, J. (2014). Recovery in fungal biomass is related to decrease in soil organic matter turnover time in a boreal fire $\begin{array}{llll}\text { chronosequence. } & \text { Geoderma, } & \text { 74-82. }\end{array}$ https://doi.org/10.1016/j.geoderma.2014.07.001

720 Kurz, W. A., Shaw, C. H., Boisvenue, C., Stinson, G., Metsaranta, J., Leckie, D., Dyk, A., Smyth, C., \& Neilson, E. T. (2013). Carbon in Canada's boreal forest - A synthesis. Environmental Reviews, 21(4), 260-292. https://doi.org/10.1139/er-2013-0041 
Lambert, M. C., Ung, C. H., \& Raulier, F. (2005). Canadian national tree aboveground biomass equations. Canadian Journal of Forest Research, 35(8). https://doi.org/10.1139/x05-112

Mack, M. C., Treseder, K. K., Manies, K. L., Harden, J. W., Schuur, E. A. G., Vogel, J. G., Randerson, J. T., \& Chapin, F. S. (2008). Recovery of Aboveground Plant Biomass and Productivity After Fire in Mesic and Dry Black Spruce Forests of Interior Alaska. Ecosystems, 11(2), 209-225. https://doi.org/10.1007/s10021-007-9117-9

Maestrini, B., Nannipieri, P., \& Abiven, S. (2015). A meta-analysis on pyrogenic organic matter induced priming effect. GCB Bioenergy, 7(4), 577-590. https://doi.org/10.1111/gcbb.12194

McRae, D. J., Conard, S. G., Ivanova, G. A., Sukhinin, A. I., Baker, S. P., Samsonov, Y. N., Blake, T. W., Ivanov, V. A., Ivanov, A. V., Churkina, T. V., Hao, W. M., Koutzenogij, K. P., \& Kovaleva, N. (2006). Variability of Fire Behavior, Fire Effects, and Emissions in Scotch Pine Forests of Central Siberia. 11(1), 45-74. https://doi.org/10.1007/s11027-006-1008-4

Michaletz, S. T., \& Johnson, E. A. (2007). How forest fires kill trees: A review of the fundamental biophysical processes. Scandinavian Journal of Forest Research, 22(6), 500-515. https://doi.org/10.1080/02827580701803544

O’Donnell, J. A., Turetsky, M. R., Harden, J. W., Manies, K. L., Pruett, L. E., Shetler, G., \& Neff, J. C. (2008). Interactive Effects of Fire, Soil Climate, and Moss on CO2 Fluxes in Black Spruce Ecosystems of Interior Alaska. Ecosystems, 12(1), 57-72. https://doi.org/10.1007/s10021-008-9206-4

O’Neill, K. P., Richter, D. D., \& Kasischke, E. S. (2006). Succession-driven changes in soil respiration following fire in black spruce stands of interior Alaska. Biogeochemistry, $80(1)$, 1-20. https://doi.org/10.1007/s10533-005-5964-7

Palviainen, M., Berninger, F., Bruckman, V. J., Köster, K., de Assumpção, C. R. M., Aaltonen, H., Makita, N., Mishra, A., Kulmala, L., Adamczyk, B., Zhou, X., Heinonsalo, J., Köster, E., \& Pumpanen, J. (2018). Effects of biochar on carbon and nitrogen fluxes in boreal forest soil. Plant and Soil, 425(1-2), 71-85. https://doi.org/10.1007/s11104-018-3568-y

Pan, Y., Birdsey, R. A., Fang, J., Houghton, R., Kauppi, P. E., Kurz, W. A., Phillips, O. L., Shvidenko, A., Lewis, S. L., Canadell, J. G., Ciais, P., Jackson, R. B., Pacala, S. W., McGuire, A. D., Piao, S., Rautiainen, A., Sitch, S., \& Hayes, D. (2011). A Large and Persistent Carbon Sink in the World's Forests. Science, 333. https://doi.org/10.1126/science.1201609 
Pereira, P., Úbeda, X., \& Martin, D. A. (2012). Fire severity effects on ash chemical composition 755 and water-extractable elements. Geoderma, 191, 105-114. https://doi.org/10.1016/j.geoderma.2012.02.005

Pumpanen, J., Kulmala, L., Linden, A., Kolari, P., Nikinmaa, E., \& Hari, P. (2015). Seasonal dynamics of autotrophic respiration in boreal forest soil estimated by continuous chamber measurements. Boreal Environment Research, 20(5), 637-650.

$R$ Core Team. In. (2021). (Version 4.1.1)

Ribeiro-Kumara, C., Köster, E., Aaltonen, H., \& Köster, K. (2020). Forest-fires-GHG: A dataset derived from a literature review on soil greenhouse gas emissions after forest fires in upland boreal forests. Version V1). https://doi.org/10.17632/v7gxtvv9z3.1

Riikonen, A., Pumpanen, J., Mäki, M., \& Nikinmaa, E. (2017). High carbon losses from established growing sites delay the carbon sequestration benefits of street tree plantings - A case study in Helsinki, Finland. Urban Forestry \& Urban Greening, 26, 85-94. https://doi.org/10.1016/j.ufug.2017.04.004

Risk, D., Kellman, L., \& Beltrami, H. (2002). Soil CO2 production and surface flux at four climate observatories in eastern Canada. Global Biogeochemical Cycles, 16(4), 69-61-69-12. https://doi.org/10.1029/2001gb001831

Rogers, B. M., Soja, A. J., Goulden, M. L., \& Randerson, J. T. (2015). Influence of tree species on continental differences in boreal fires and climate feedbacks. Nature Geoscience, 8(3), 228234. https://doi.org/10.1038/ngeo2352

Ryan, K. C. (2002). Dynamic Interactions between Forest Structure and Fire Behavior in Boreal 775 Ecosystems. Silva Fennica, 36(1), 13-39.

Sanchez-Garcia, C., Santin, C., Doerr, S. H., Strydom, T., \& Urbanek, E. (2021). Wildland fire ash enhances short-term CO2 flux from soil in a Southern African savannah. Soil Biology and Biochemistry.

Santín, C., Doerr, S. H., Merino, A., Bryant, R., \& Loader, N. J. (2016). Forest floor chemical transformations in a boreal forest fire and their correlations with temperature and heating duration. Geoderma, 264, 71-80. https://doi.org/10.1016/j.geoderma.2015.09.021

Santín, C., Doerr, S. H., Preston, C., \& Bryant, R. (2013). Consumption of residual pyrogenic carbon by wildfire. International Journal of Wildland Fire, 22(8). https://doi.org/10.1071/wf12190 
Santín, C., Doerr, S. H., Preston, C. M., \& Gonzalez-Rodriguez, G. (2015). Pyrogenic organic matter production from wildfires: a missing sink in the global carbon cycle. Glob Chang Biol, 21(4), 1621-1633. https://doi.org/10.1111/gcb.12800

SAS Institute Inc. In. (2021). (Version 14.1)

Sawamoto, T., Hatano, R., \& Shibuya, M. (2001). CO2, N2O, and CH4 Fluxes from Soil in 790 Siberian-Taiga Larch Forests with Different Histories of Forest Fire. Tohoko geophysical journal.

Sawamoto, T., Hatano, R., Yajima, T., Takahashi, K., \& Isaev, A. P. (2000). Soil respiration in Siberian Taiga ecosystems with different histories of forest fire. Soil Science and Plant Nutrition, 46(1), 31-42. https://doi.org/10.1080/00380768.2000.10408759

Seedre, M., Shrestha, B. M., Chen, H. Y. H., Colombo, S., \& Jõgiste, K. (2011). Carbon dynamics of North American boreal forest after stand replacing wildfire and clearcut logging. Journal of Forest Research, 16(3), 168-183. https://doi.org/10.1007/s10310-011-0264-7

Song, J., Liu, Z., Zhang, Y., Yan, T., Shen, Z., \& Piao, S. (2019). Effects of wildfire on soil respiration and its heterotrophic and autotrophic components in a montane coniferous forest. Journal of Plant Ecology, 12(2), 336-345. https://doi.org/10.1093/jpe/rty031

Stocks, B. J., Alexander, M. E., Wotton, B. M., Stefner, C. N., Flannigan, M. D., Taylor, S. W., Lavoie, N., Mason, J. A., Hartley, G. R., Maffey, M. E., Dalrymple, G. N., Blake, T. W., Cruz, M. G., \& Lanoville, R. A. (2004). Crown fire behaviour in a northern jack pine-black spruce forest. Canadian Journal of Forest Research, 34(8), 1548-1560. https://doi.org/10.1139/x04-054

Swezy, D. M., \& Agee, J. K. (1991). Prescribed-fire effects on fine-root and tree mortality in oldgrowth ponderosa pine. Canadian Journal of Forest Research, 21(5), 626-634. https://doi.org/10.1139/x91-086

Takakai, F., Desyatkin, A. R., Lopez, C. M. L., Fedorov, A. N., Desyatkin, R. V., \& Hatano, R. 810 (2010). Influence of forest disturbance on CO2, CH4and N2O fluxes from larch forest soil in the permafrost taiga region of eastern Siberia. Soil Science and Plant Nutrition, 54(6), 938-949. https://doi.org/10.1111/j.1747-0765.2008.00309.x

Wang, W., Wang, H., Zu, Y., Li, X., \& Koike, T. (2006). Characteristics of the temperature coefficient, Q10, for the respiration of non-photosynthetic organs and soils of forest ecosystems. Front. For. China https://doi.org/10.1007/s 11461-006-0018-4 
Wirth, C. (2005). Fire Regime and Tree Diversity in Boreal Forests: Implications for the Carbon Cycle. In Forest Diversity and Function (pp. 309-344). https://doi.org/10.1007/3-54026599-6 15

Zhao, B., Zhuang, Q., Shurpali, N., Köster, K., Berninger, F., \& Pumpanen, J. (2020). North 820 American boreal forests are a large carbon source due to wildfires from 1986 to 2016. https://doi.org/ 10.21203/rs.3.rs-108154/v1

\section{Tables}


Table 1. Details of experimental sites, fires, weather during ignition ( $\mathrm{T}_{\text {air }}$, air temperature, $\mathrm{RH}$, relative humidity, WS, wind speed), heating indicators at the forest floor during fire $\left(\mathrm{T}_{\max }\right.$, mean maximum temperature, $\mathrm{T}_{\text {res }}$, mean duration at which temperature $>$ $300{ }^{\circ} \mathrm{C}$ ), and numeric ratings of the Canadian Forest Fire Weather Index System (FFMC, Fine Fuel Moisture Code, DMC, Duff Moisture Code, DC, Drought Code, BUI, Buildup Index, ISI, Initial Spread Index and FWI, Fire Weather Index; n.d., no data).

\begin{tabular}{|c|c|c|c|c|c|c|c|c|c|c|c|c|c|c|c|c|c|}
\hline \multirow{2}{*}{$\begin{array}{l}\text { Dominant } \\
\text { tree } \\
\text { species }\end{array}$} & \multirow[t]{2}{*}{ Type of fire } & \multicolumn{2}{|c|}{ Time of fire } & \multirow{2}{*}{$\begin{array}{r}\text { Tree } \\
\text { density } \\
\\
(\text { stems } \\
\left.\text { ha-1) }^{-1}\right) \\
\end{array}$} & \multirow{2}{*}{$\begin{array}{l}\mathrm{T}_{\text {air }} \\
\left({ }^{\circ} \mathrm{C}\right)\end{array}$} & \multirow{2}{*}{$\begin{array}{l}\mathrm{RH} \\
\text { (\%) }\end{array}$} & \multirow{2}{*}{$\begin{array}{r}\text { WS } \\
\left(\mathrm{km} \mathrm{h}^{-1}\right)\end{array}$} & \multirow{2}{*}{$\begin{array}{r}\text { Flame } \\
\text { length } \\
\text { (m) }\end{array}$} & \multirow{2}{*}{$\begin{array}{r}\text { Estimated } \\
\text { fire } \\
\text { intensity } \\
\left(\mathrm{kW} \mathrm{m} \mathrm{m}^{-1}\right)\end{array}$} & \multirow{2}{*}{$\begin{array}{c}\mathrm{T}_{\max }{ }^{*} \\
\left({ }^{\circ} \mathrm{C}\right)\end{array}$} & \multirow{2}{*}{$\begin{array}{r}T_{\text {res }}{ }^{*} \\
(\mathrm{~s})\end{array}$} & \multicolumn{6}{|c|}{ Canadian Forest Fire Weather Index System } \\
\hline & & & & & & & & & & & & FFMC & DMC & DC & BUI & ISI & FWI \\
\hline \multirow[t]{5}{*}{ Jack pine } & Surface fire & 2 Aug & 2018 & 1416 & 29 & 43 & 10.7 & $\begin{array}{r}0.25- \\
0.5\end{array}$ & $<500$ & n.d. & n.d. & 85 & n.d. & n.d. & 54 & 3.3 & 9.6 \\
\hline & Surface fire & 3 Aug & 2017 & n.d. & 28 & 35 & 10.0 & 1.5 & 2500 & 294 & 298 & 91 & 92 & 491 & 126 & 8.0 & 30.0 \\
\hline & Surface fire & 23 Jun & 2015 & 2433 & 28 & 27 & 8.2 & $\begin{array}{r}0.25- \\
0.5\end{array}$ & $<500$ & n.d. & n.d. & 90 & 106 & 645 & 151 & 7.0 & 29.0 \\
\hline & Crown fire & 23 Jun & 2015 A & 6635 & 28 & 27 & 8.2 & $2.5-4$ & 6000 & n.d. & n.d. & 90 & 106 & 645 & 151 & 7.0 & 29.0 \\
\hline & Crown fire & 25 Jun & 2015 B & 6500 & 27 & 28 & 6.6 & $>4$ & 8000 & 758 & 218 & 90 & 86 & 640 & 129 & 6.0 & 26.0 \\
\hline Black & Crown fire & 2 Aug & 2017 & 8222 & 30 & 25 & 9.4 & $2.5-3$ & 6000 & 546 & 398 & 93 & 89 & 483 & 122 & 10.0 & 35.0 \\
\hline spruce & Crown fire & 30 Jun & 2016 & 8222 & 31 & 30 & 14.1 & $>4$ & $>8000$ & 825 & 189 & 93 & 54 & 400 & 81 & 12.6 & 33.1 \\
\hline
\end{tabular}

* Determined as in Santín et al. (2013); Santín et al. (2015).

Table 2. Mean soil properties in the unburned sites and sites burned by experimental surface and crown fires. Values for soil temperature and soil moisture are least squares means \pm standard error. Values for humic layer depth are observed means.

\begin{tabular}{|c|c|c|c|c|c|c|c|}
\hline \multirow{2}{*}{$\begin{array}{l}\text { Dominant tree } \\
\text { species }\end{array}$} & \multirow[t]{2}{*}{ Type of fire } & \multirow[t]{2}{*}{ Time of fire } & \multirow[t]{2}{*}{ Time after fire } & \multirow{2}{*}{$\begin{array}{l}\text { Humic layer } \\
\text { depth }(\mathrm{cm})\end{array}$} & \multicolumn{2}{|c|}{ Soil temperature $\left({ }^{\circ} \mathrm{C}\right)$} & \multirow{2}{*}{$\begin{array}{l}\text { Soil moisture (\%) } \\
5 \mathrm{~cm} \text { depth }\end{array}$} \\
\hline & & & & & $5 \mathrm{~cm}$ depth & $10 \mathrm{~cm}$ depth & \\
\hline \multirow[t]{6}{*}{ Jack pine } & Control & 1931 & 87 years & 2.6 & $14.94 \pm 0.40^{c}$ & $14.21 \pm 0.32^{c}$ & $17.73 \pm 1.70^{\text {cd }}$ \\
\hline & Surface fire & 2018 & 0 year & 1.9 & $15.01 \pm 0.40^{c}$ & $14.42 \pm 0.32^{b c}$ & $14.84 \pm 1.70^{d}$ \\
\hline & Surface fire & 2017 & 1 year & 1.8 & $16.13 \pm 0.49 b c$ & $15.43 \pm 0.39 \mathrm{abc}$ & $16.04 \pm 2.08^{\mathrm{cd}}$ \\
\hline & Surface fire & 2015 & 3 years & 1.9 & $17.29 \pm 0.60^{b}$ & $16.11 \pm 0.48^{a b}$ & $24.04 \pm 2.54^{b c}$ \\
\hline & Crown fire & $2015 \mathrm{~A}$ & 3 years & 3.0 & $17.40 \pm 0.38^{b}$ & $14.99 \pm 0.30^{a b c}$ & $31.77 \pm 1.61^{\mathrm{ab}}$ \\
\hline & Crown fire & 2015 B & 3 years & 1.1 & $21.03 \pm 0.60^{a}$ & $16.63 \pm 0.48^{a}$ & $35.49 \pm 2.54^{\mathrm{a}}$ \\
\hline \multirow[t]{3}{*}{ Black spruce } & Control & 1931 & 87 years & 6.1 & $14.74 \pm 0.47^{\mathrm{B}}$ & $11.53 \pm 0.27^{B}$ & $38.54 \pm 2.54^{\mathrm{A}}$ \\
\hline & Crown fire & 2017 & 1 year & 3.1 & $17.26 \pm 0.62^{\mathrm{A}}$ & $15.74 \pm 0.36^{A}$ & $28.69 \pm 3.36^{\mathrm{AB}}$ \\
\hline & Crown fire & 2016 & 2 years & 2.7 & $19.26 \pm 0.58^{A}$ & $15.32 \pm 0.34^{\mathrm{A}}$ & $23.72 \pm 3.17^{B}$ \\
\hline
\end{tabular}

830 Different lowercase superscript letters represent significant differences between pine-dominated experimental sites at Tukey $(\mathrm{P}<0.05)$. Different uppercase superscript letters represent significant differences between spruce-dominated experimental sites at Tukey $(P<0.05)$. 


\section{Figure captions}

Figure 1. Geographical location of the Fort Providence Wildfire Experimental Site (Fort Providence, Northwest Territories, Canada) with the approximate location of the experimental sites 835 where the field sampling took place. Map created using ArcGIS ${ }^{\circledR}$ software by Esri. Base map from Esri, Maxar, GeoEye, Earthstar Geographics, CNES/Airbus DS, USDA, USGS, AeroGRID, IGN, and the GIS User Community (Esri, 2021).

Figure 2. Photographs of experimental sites for a: Unburned jack pine-dominated site (Control P). b: 2018 surface fire (SF 2018) immediately after the fire. c: 2017 surface fire (SF 2017) 1 year after the fire. d: surface fire (SF 2015) 3 years after the fire. e: 2015 crown fire (CF 2015 A) 3 years after the fire. f: 2015 crown fire (CF 2015 B) 3 years after the fire. g: surface fire (SF 2015) immediately after the fire. h: 2015 crown fire (CF 2015 A) immediately after the fire. i: Unburned black sprucedominated site (Control S). j: 2017 crown fire (CF 2017) 1 year after the fire. k: 2016 crown fire (CF 2016) 2 years after the fire.

845 Figure 3. Mean aboveground biomass and necromass $\left(\mathrm{kg} \mathrm{m}^{-2}\right)$ in pine (P)- or spruce (S)-dominated, unburned sites and sites burned by experimental surface (SF) and crown (CF) fires. a-c: Understory biomass. d-f: Woody necromass. g: Living tree stem biomass. h: The sum of mean living tree stem, regeneration sapling, and understory biomasses. Dots are positioned according to the observed means.

850 Figure 4. Box plots of soil temperature and soil moisture values in pine (P)- or spruce (S)dominated, unburned (control) sites and sites burned by experimental surface (SF) and crown (CF) fires. a: Soil temperature at $10 \mathrm{~cm}$ depth $\left(\mathrm{ST}_{10},{ }^{\circ} \mathrm{C}\right)$. b: Soil temperature at $5 \mathrm{~cm}$ depth $\left(\mathrm{ST}_{5},{ }^{\circ} \mathrm{C}\right)$. c: Soil moisture (SM, \%). Filled symbols represent spruce-dominated sites and unfilled symbols pinedominated sites. CF 2015 includes both CF 2015 A and CF 2015 B experimental fires.

855 Figure 5. Box plots of soil surface $\mathrm{CO}_{2}$ efflux $\left(\mathrm{R}_{\mathrm{S}}\right)$ and temperature-adjusted soil surface $\mathrm{CO}_{2}$ efflux $\left(\mathrm{R}_{\mathrm{T}}\right)$ values in pine $(\mathrm{P})$ - or spruce $(\mathrm{S})$-dominated, unburned (control) sites and sites burned by experimental surface (SF) and crown (CF) fires. Filled symbols represent spruce-dominated sites and unfilled symbols pine-dominated sites. CF 2015 includes both CF 2015 A and CF 2015 B experimental fires.

860 Figure 6. Least squares means of soil $\mathrm{CO}_{2}$ efflux $\left(\mathrm{g} \mathrm{CO}_{2} \mathrm{~m}^{-2} \mathrm{~d}^{-1}\right)$ partitioning from autotrophic $\left(\mathrm{R}_{\mathrm{A}}\right)$ and heterotrophic respiration $\left(\mathrm{R}_{\mathrm{H}}\right)$ in unburned (control) and burned experimental sites by experimental surface and crown fires. a: Mean temperature-adjusted $\left(10{ }^{\circ} \mathrm{C}\right)$ soil surface $\mathrm{CO}_{2}$ flux $\left(\mathrm{R}_{\mathrm{T} 10}\right)$ excluding $\mathrm{CO}_{2}$ efflux from incubated humic and mineral (5 $\mathrm{cm}$ depth) layers (i.e., $\left.\mathrm{R}_{\mathrm{A}}\right)$. b: Mean soil $\mathrm{CO}_{2}$ efflux from the sum of incubated humic and mineral $\left(5 \mathrm{~cm}\right.$ depth) layers at $10{ }^{\circ} \mathrm{C}$

865 (i.e., $\left.\mathrm{R}_{\mathrm{H}}\right)$. Lowercase letters indicate significant differences at Tukey $(\mathrm{P}<0.05)$ between $\mathrm{CO}_{2}$ efflux means within pine-dominated sites. Uppercase letters indicate significant differences at Tukey $(\mathrm{P}$ $<0.05$ ) between $\mathrm{CO}_{2}$ efflux means within spruce-dominated sites. Error bars show upper and lower $95 \%$ confidence intervals. \% values denote the ratio of either $R_{A}: R_{T 10}$ or $R_{H}: R_{T 10}$. CF 2015 includes both CF 2015 A and CF 2015 B experimental fires. 


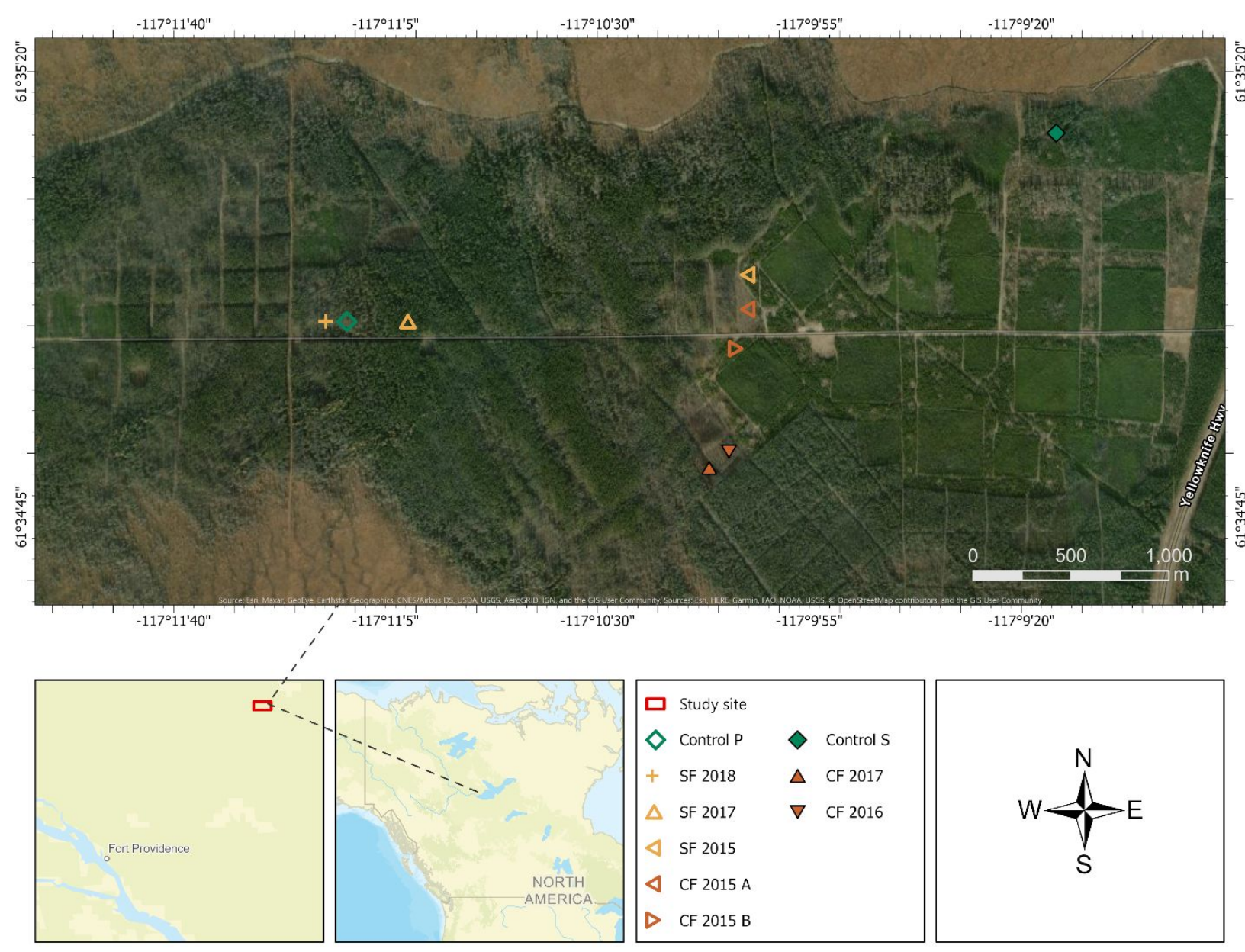

Figure 1 


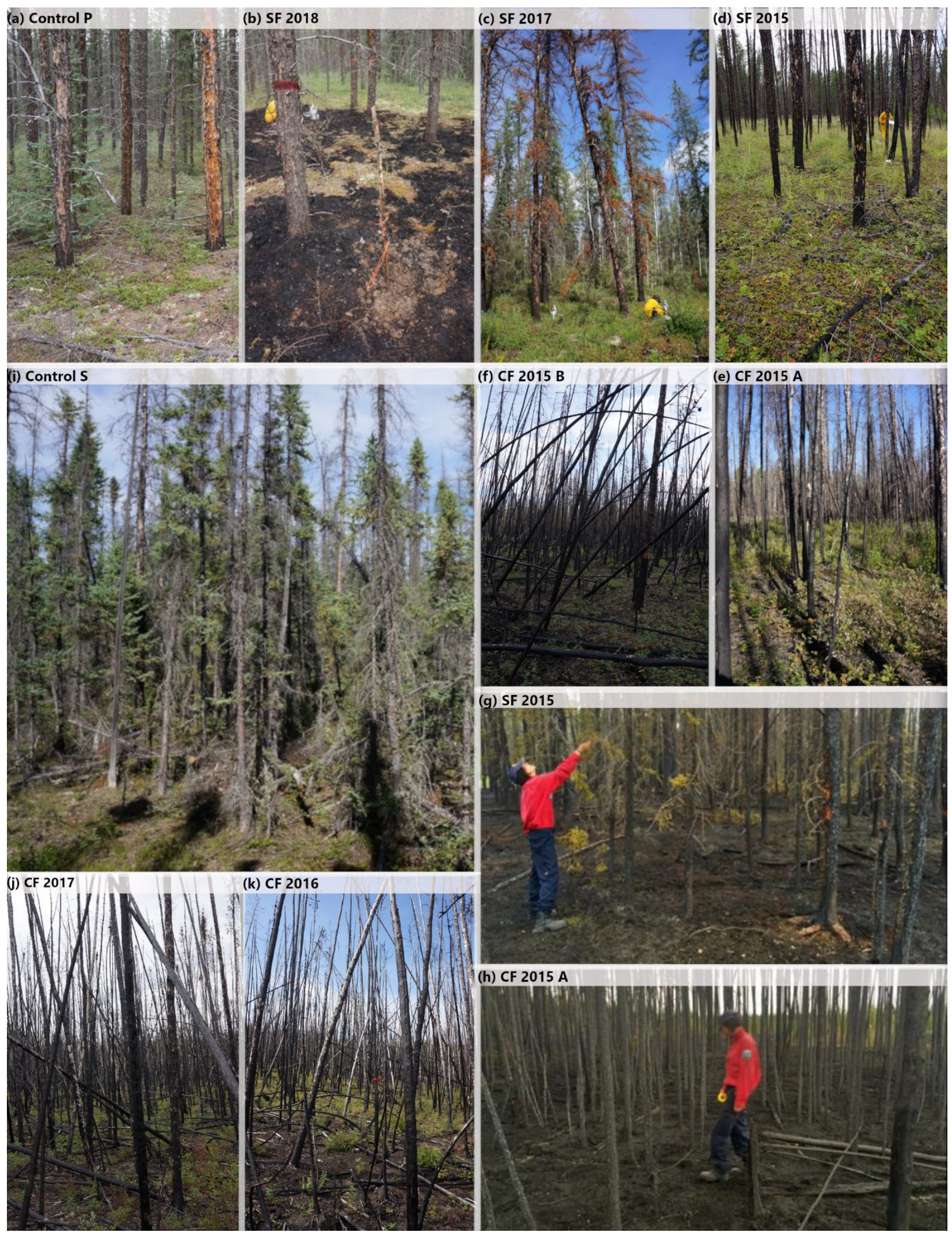

$875 \quad$ Figure 2 
(a)

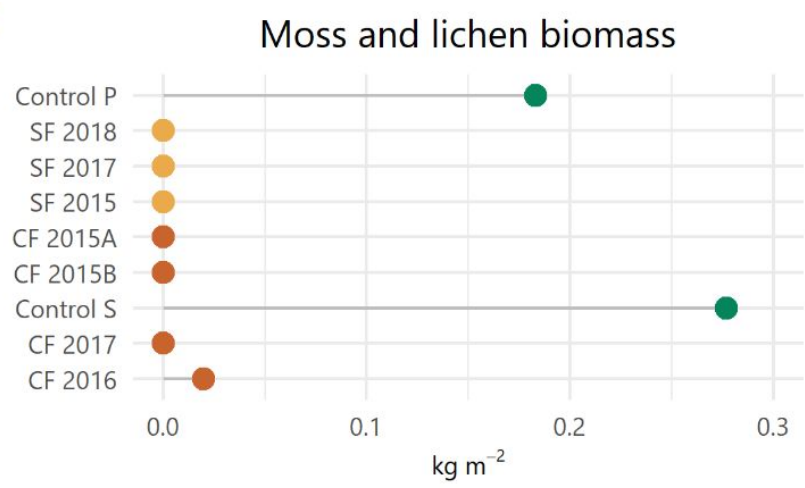

(b)

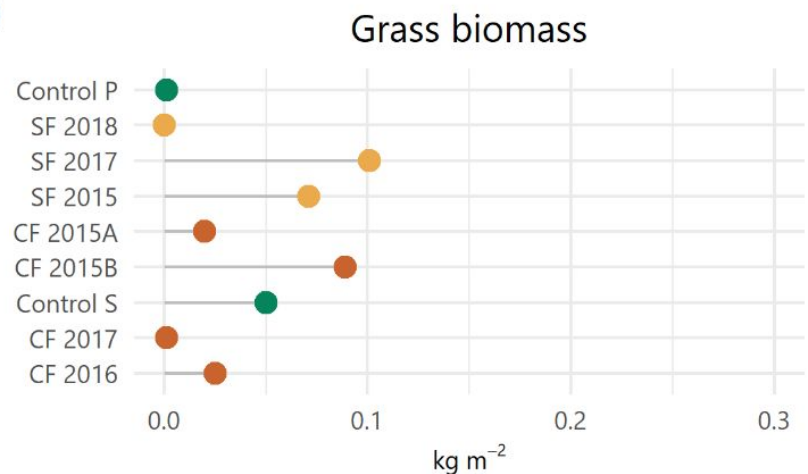

(c)

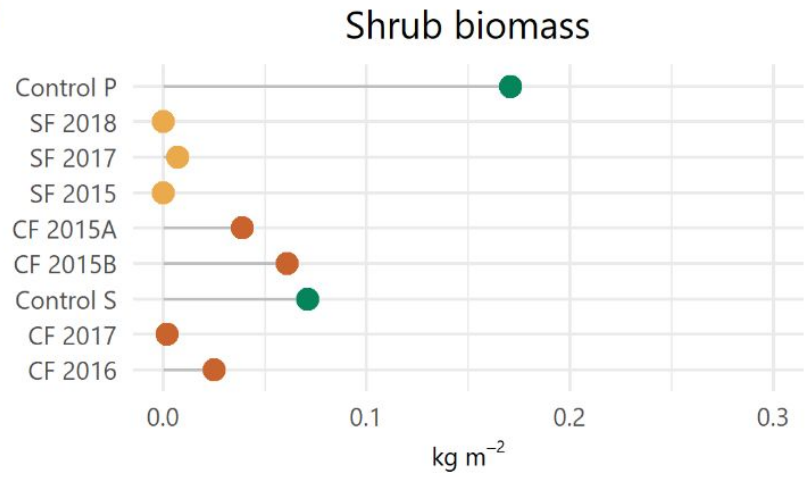

(d)

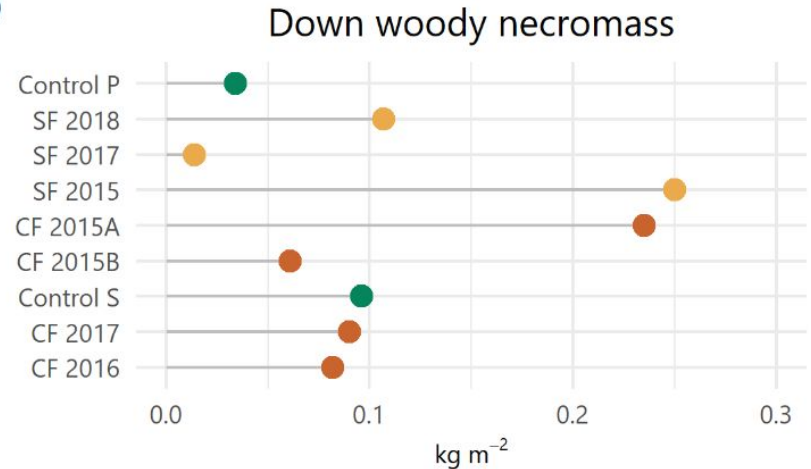

(e)

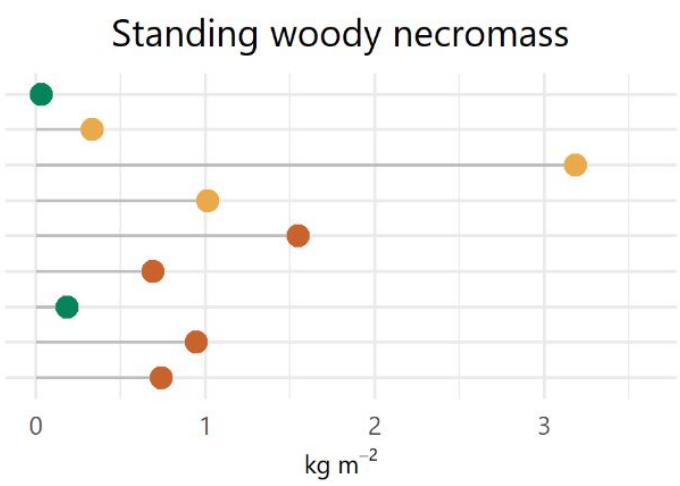

(f)

Total woody necromass

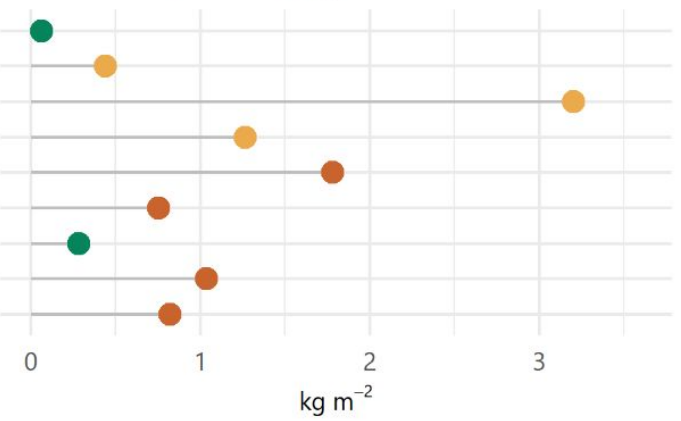

(g)
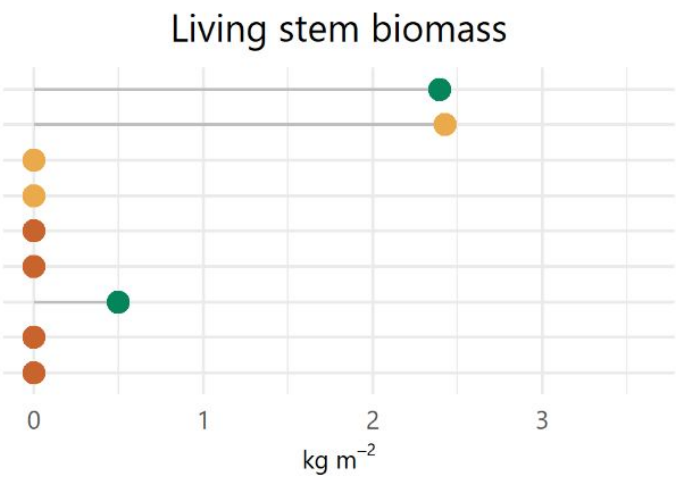

(h) Total living aboveground biomass

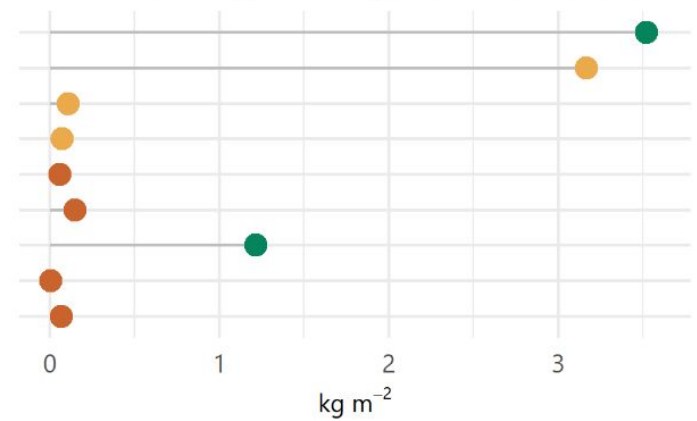

Figure 3 


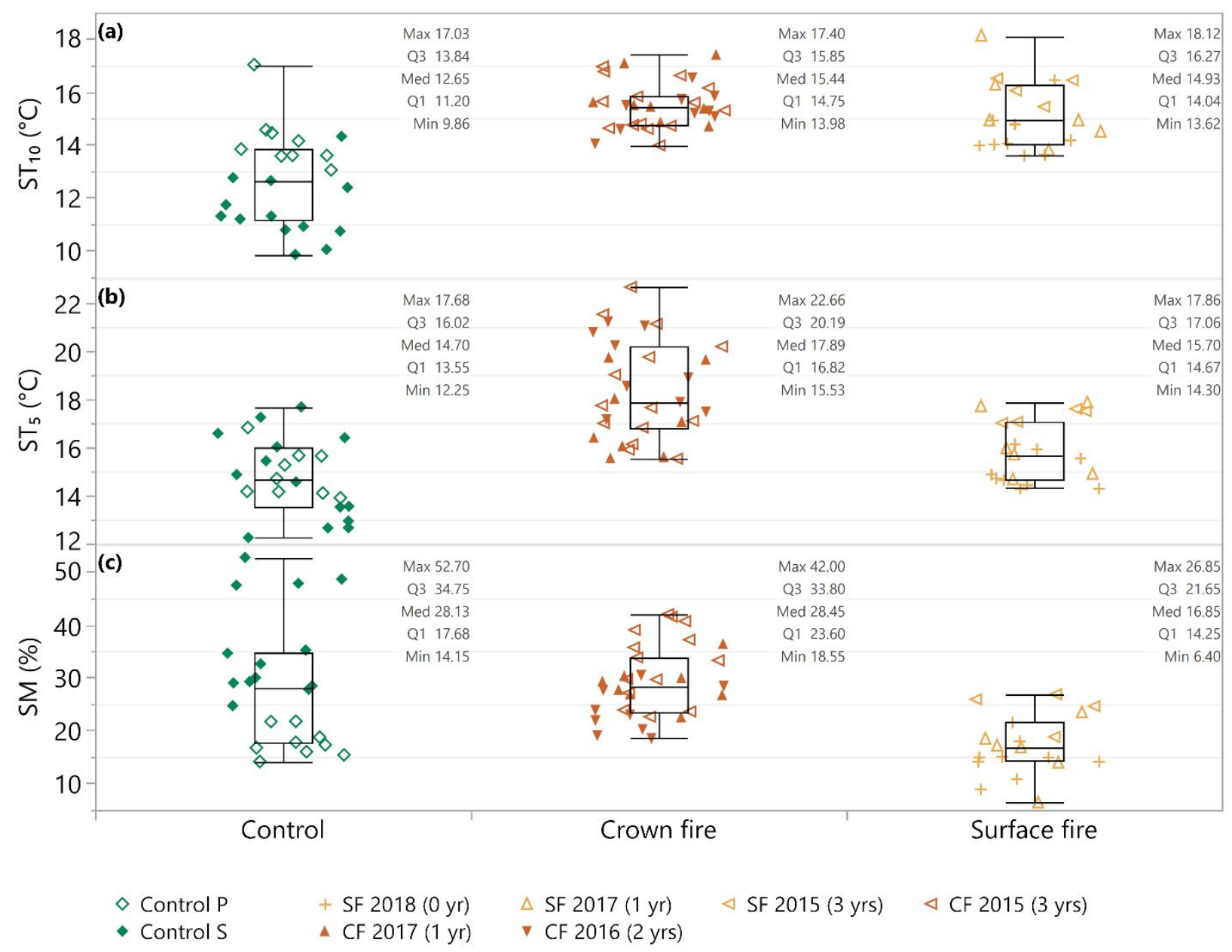

Figure 4 


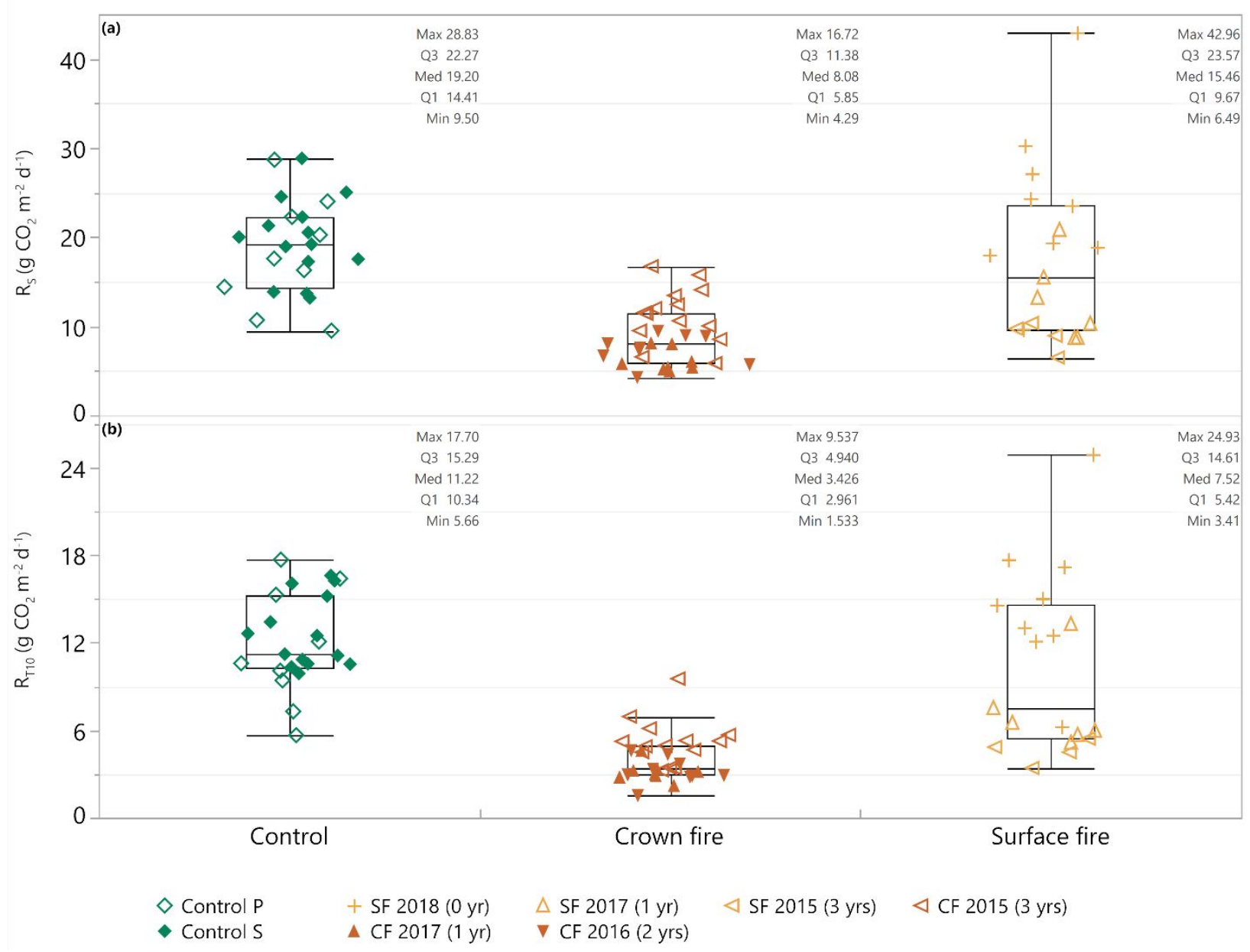

Figure 5 


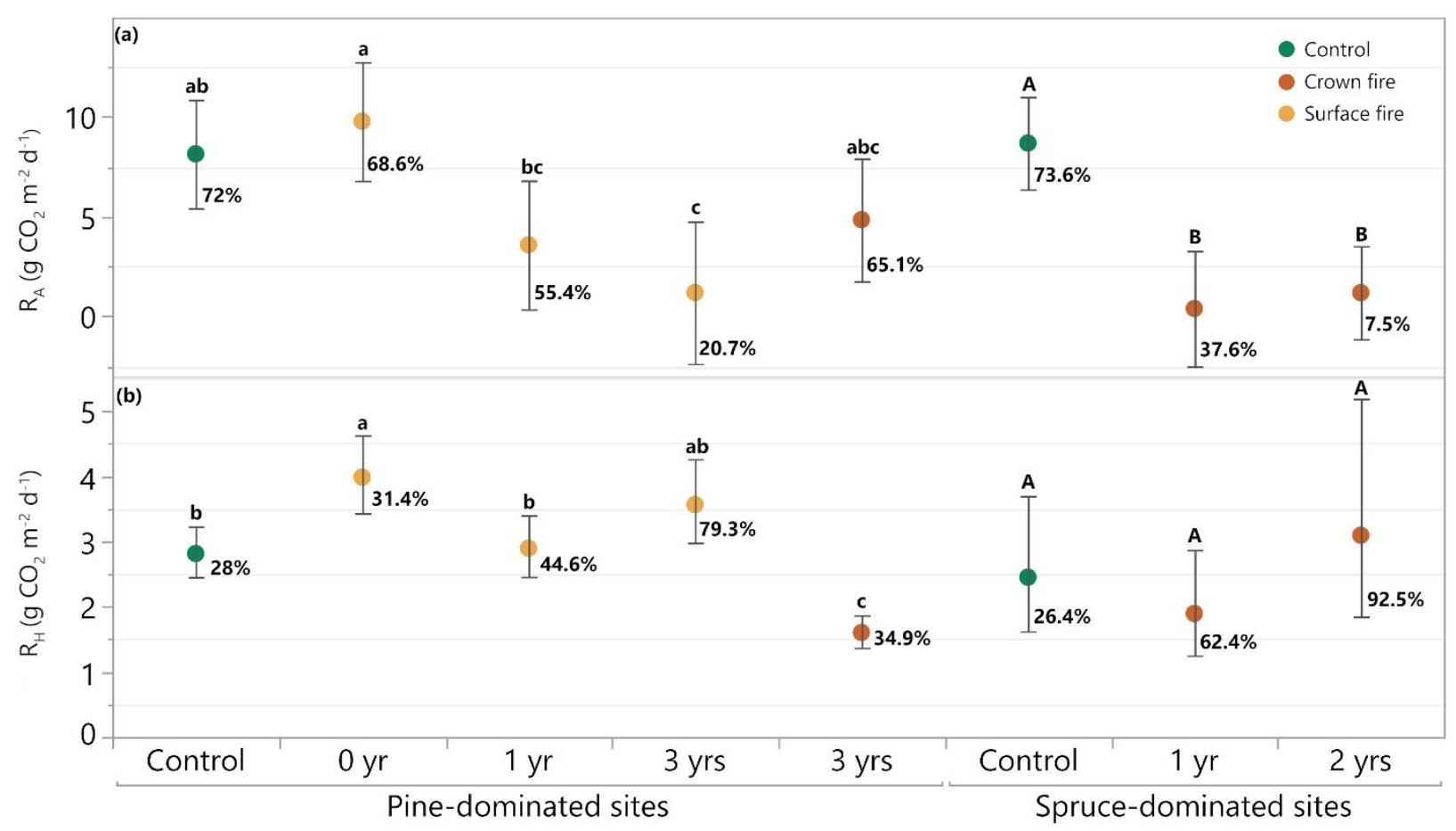

885

Figure 6 


\section{$\underline{\text { Supplementary information }}$}

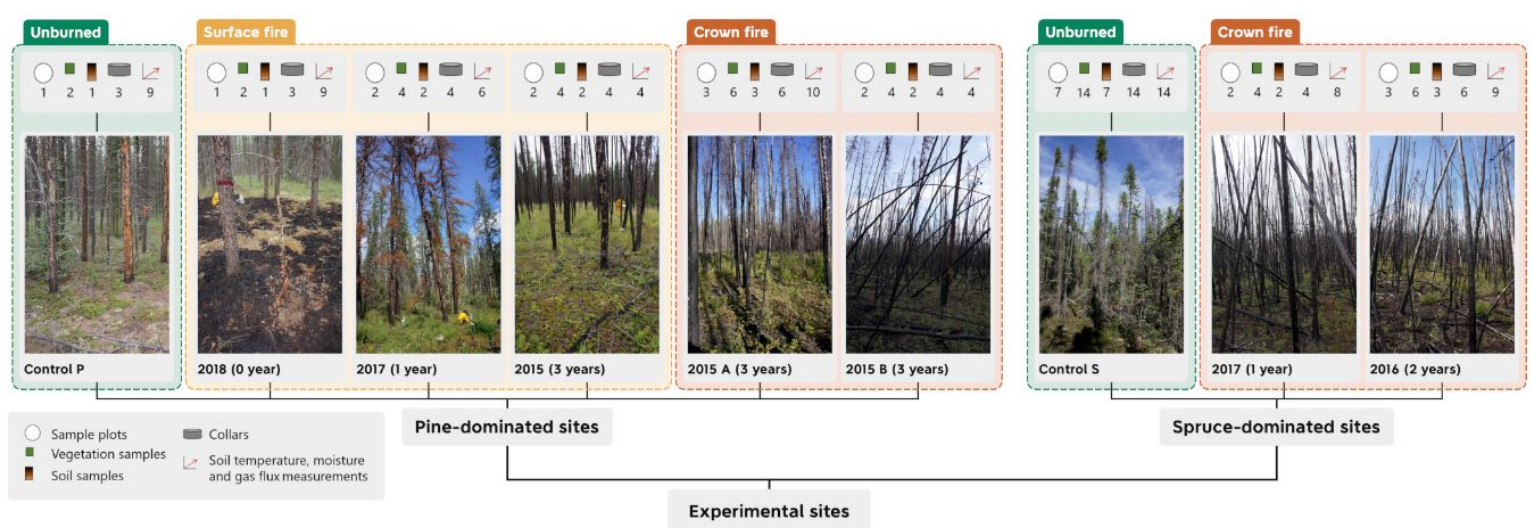

S1. Experimental sites at the Canadian Boreal Community FireSmart Project wildfire experimental site (Fort Providence, Northwest Territories, Canada) including information on the number of sample plots, vegetation and soil samples, collars, and measurements. Each photo represents the state of each experimental site during the field sampling time (August 2018).

Three pairs of collars were juxtaposed in three extremities of the burned plot about $4 \mathrm{~m}$ away from each other, according to shown in Figure S2.

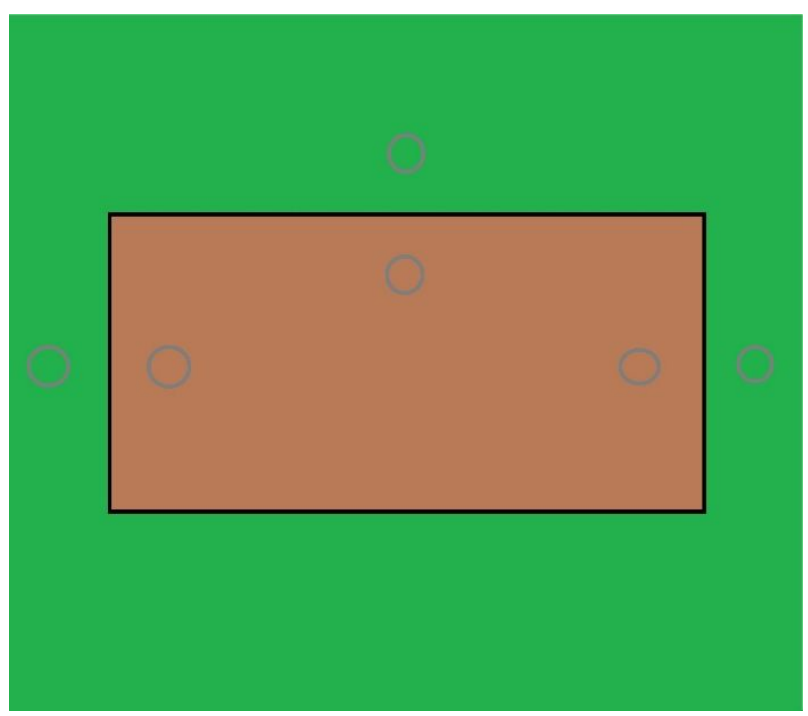

S2. Disposition of collars in burned (brown) and unburned (green) plots. Not to scale. 
(a)

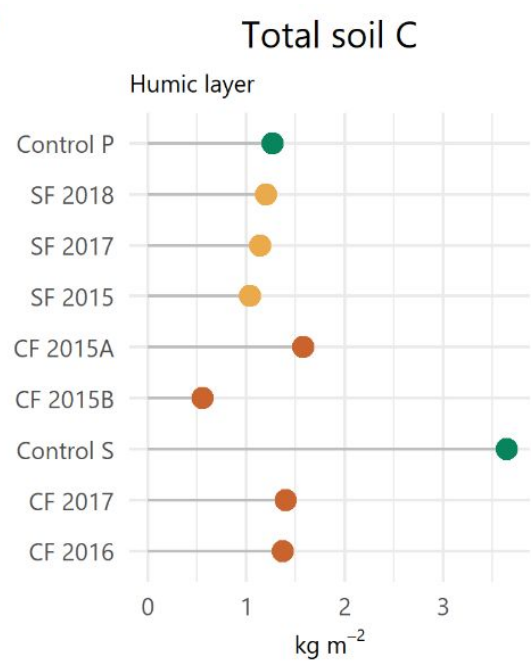

(b)

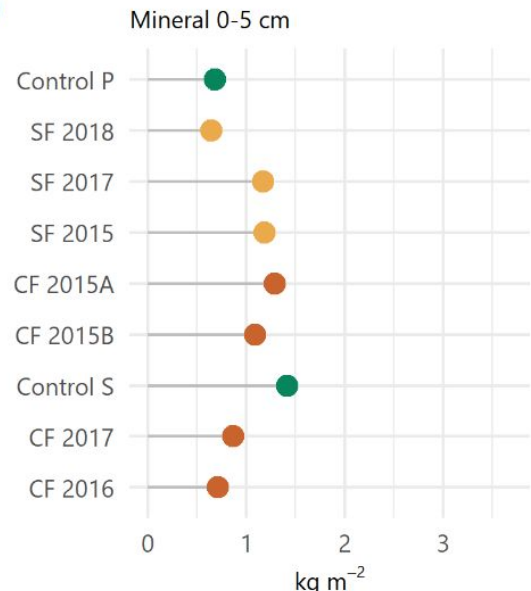

(c)

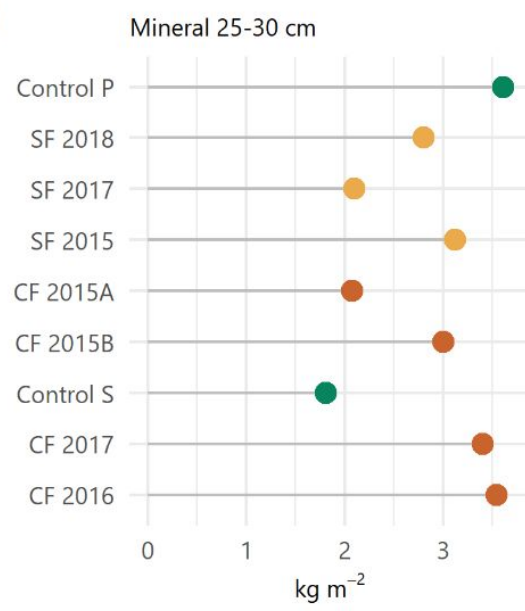

(d) Total soil $\mathrm{N}$

Humic laye

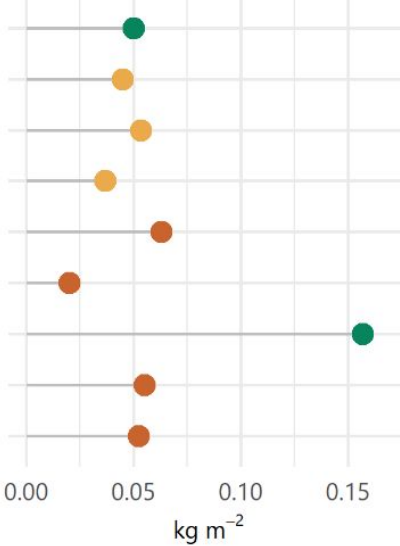

(e)

Mineral 0-5 cm

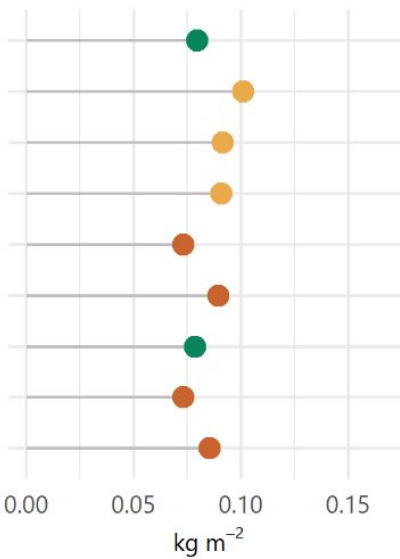

(f)

Mineral $25-30 \mathrm{~cm}$

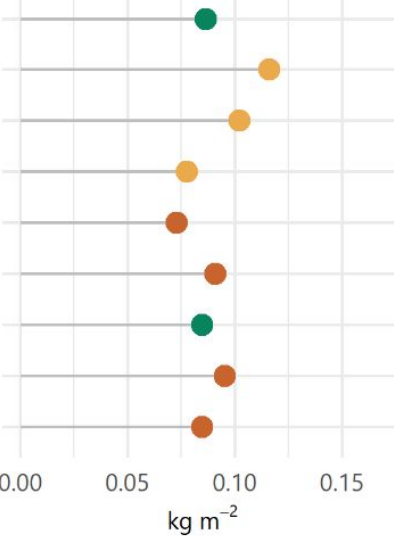

(g) Soil pH

Humic layer

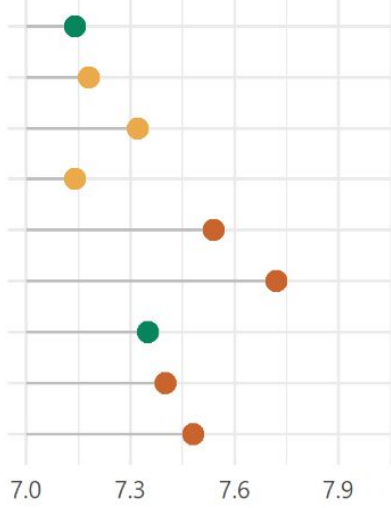

(h) Mineral 0-5 cm

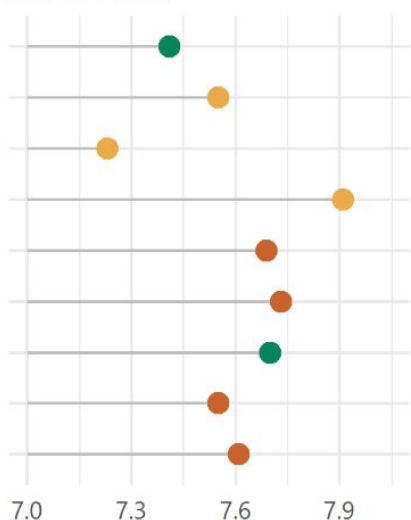

(i)

Mineral $25-30 \mathrm{~cm}$

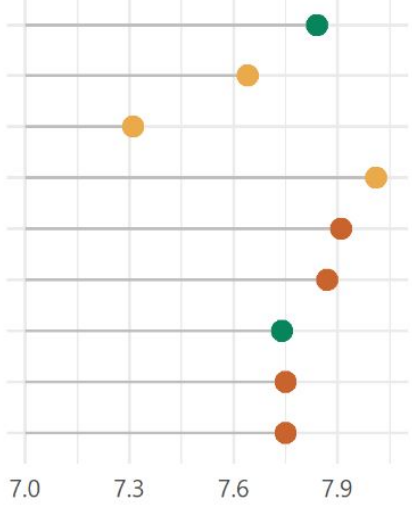

- Control Crown fire Surface fire

S3. Mean soil properties in the humic and mineral layer (at 0-5 and 25-30) of unburned (control) and burned sites by experimental surface (SF) and crown (CF) fires in pine (P)- and spruce (S)-dominated sites. a-c: Total soil carbon (C) content. d-f: Total soil nitrogen (N) content. g-i: Soil pH. Dots are positioned according to the observed means. 